NBER WORKING PAPER SERIES

IS HIGH SCHOOL EMPLOYMENT

CONSUMPTION OR INVESTMENT?

Christopher J. Ruhm

Working Paper No. 5030

NATIONAL BUREAU OF ECONOMIC RESEARCH

1050 Massachusetts Avenue

Cambridge, MA 02138

February 1995

I thank seminar participants at Duke University, the U.S. Department of Labor, and the University of North Carolina Greensboro for helpful comments and Jason Herman for research assistance. Financial support is gratefully acknowledged from the U.S. Department of Labor (contract no. 41USC252C3), and the National Institute on Alcohol Abuse and Alcoholism (grant no. AA09268-01A1). This paper is part of NBER's research program in Labor Studies. Any opinions expressed are those of the author and not those of the National Bureau of Economic Research.

(C) 1995 by Christopher J. Ruhm. All rights reserved. Short sections of text, not to exceed two paragraphs, may be quoted without explicit permission provided that full credit, including (C) notice, is given to the source. 
IS HIGH SCHOOL EMPLOYMENT

CONSUMPTION OR INVESTMENT?

\begin{abstract}
$\underline{\text { ABSTRACT }}$
Using data from the National Longitudinal Survey of Youth, this study examines whether employment by high school students improves or worsens economic attainment 6 to 9 years after the scheduled date of high school graduation. There is no indication that light to moderate job commitments ever have a detrimental impact and hours worked during the senior grade are positively correlated with future earnings, fringe benefits, and occupational status. These results are robust across a variety of specifications and suggest that employment increases net investments in human capital and facilitates the school-to-work transition, particularly towards the end of high school and for students not continuing on to college.
\end{abstract}

Christopher J. Ruhm

Department of Economics

University of North Carolina Greensboro

Greensboro, NC 27412-5001

and NBER 


\section{Is High School Employment Consumption or Investment?}

\section{Introduction}

During the middle 1970s, several prestigious commissions studying the problems of adolescents (e.g. President's Science Advisory Committee, 1974; National Commission on the Reform of Secondary Education, 1973; National Panel on High Schools and Adolescent Education, 1975) reached the common conclusion that additional early work experience would foster the development of personal responsibility, smooth the transition from youth to adulthood, and improve educational performance and occupational attainment. Shortly thereafter, a number of federal initiatives (e.g. the Career Education Incentive Act of 1977) were passed with the goal of expanding the employment experience of youths.

These recommendations were made in the absence of hard empirical evidence that increased job-holding causes or even is correlated with favorable outcomes. Economic theory also fails to provide unambiguous predictions concerning the efficacy of youth employment. For example, time devoted to jobs could detract from potentially more beneficial educational investments in human capital. Conversely, the employment might provide skills and knowledge which increase future productivity and complement in-class learning. ${ }^{1}$ Early work experience could also speed the process by which youths obtain positions providing a good match between job requirements and worker qualifications. ${ }^{2}$

Given these ambiguities, it is not surprising that a partial reappraisal of the benefits and costs of student employment occurred during the 1980s. The seminal research of Greenberger \& Steinberg and their co-authors (Greenberger \& Steinberg, 1980; Greenberger et. al. 1982;

Similarly, sociologists have suggested zero-sum models whereby employment is a diversion from academic pursuits and developmental models where work experience furthers the total development of individuals.

2 Topel \& Ward (1992) provide evidence of frequent job changing for inexperienced workers and argue that this is an important source of wage and productivity increases. 
Steinberg et. al. 1982a, 1982b) indicated generally negative outcomes, leading them to conclude that "working is more likely to interfere with than enhance schooling; promotes pseudomaturity rather than maturity; is associated in certain circumstances with higher, not lower, rates of delinquency and drug and alcohol use; and fosters cynical rather than respectful attitudes toward work" (Greenberger \& Steinberg, 1986: p. 235). Furthermore, recent research suggests that youths take jobs to finance short-term consumption, rather than to enhance human capital investments. $^{3}$

These concerns have provided justification for recent efforts to strengthen enforcement of the child labor provisions in the Fair Labor Standards Act and for some states to place additional restrictions on the employment of minors. ${ }^{4}$ Reflecting continuing uncertainty over the net benefits of job-holding by youths, however, other states have simultaneously liberalized child labor laws and the federal government enacted the School-to-Work Opportunities Act in 1994, which provides competitive grants to states developing programs emphasizing work-based learning, employer involvement, and paid work by students.

It is important to better understand the effects of high school work experience. Rates of employment by in-school youths are at historically high levels. If this job-holding has the negative effects sometimes attributed to it and, in particular, if it reduces educational attainment and academic performance, the elevated work propensities could explain a portion of the wage stagnation observed over the last two decades, especially among young workers without college educations. Conversely, if early labor market experience has favorable impacts on

3 For example, $69 \%$ of working high school seniors, in the 1982 High School and Beyond Survey, report spending some of their earnings for car expenses, $97 \%$ to "buy things", but just $44 \%$ towards saving for college (Yeatts, 1994).

4 See Brooks (1991) for a description of the enforcement efforts and Nelson (1994) for a summary of changes in state labor laws occurring during 1993. 
future economic outcomes, the relatively low employment rates of nonwhite youths could contribute to racial earnings gaps observed later in life.

Previous research suffers from two fundamental shortcomings which make it difficult to determine the net benefits or costs of job-holding by students. First, most studies treat youth employment as exogenous, ignoring the selection process determining which students work and, conditional upon doing so, how many hours they are employed. Indeed, much of the prior investigation has used unrepresentative samples and held constant few, if any, individual characteristics. Second, analysts have focused upon educational achievement and employment outcomes shortly after the completion of high school but have obtained little information on long-run labor market success.

Using data from the National Longitudinal Survey of Youth (NLSY), this paper improves in both areas. Several strategies are used to account for differences between workers and nonworkers. These entail controlling for an unusually comprehensive set of background characteristics, examining whether reduced form estimates are biased by the potential endogeneity of high school employment, and testing the robustness of key results to changes in samples and specifications. The dependent variables are employment consequences 6 to 9 years after the scheduled date of high school graduation, thus providing the best available information on long-term effects of the student job-holding. This study also examines a diverse set of economic outcomes and utilizes better information on high school employment status than has previously been available. The analysis focuses upon the number of hours worked by high school students. Examining the role of job characteristics or of employment by college students is beyond the scope of this investigation and is reserved for the future..$^{5}$

5 See Greenberger \& Steinberg (1986), Greenberger et. al. (1982) Stern \& Nakata (1989), and Stern et. al. (1990) for discussion of differences in job characteristics. 
The analysis reveals no evidence of detrimental effects of low to moderate amounts of student employment. To the contrary, job-holding in the senior year is associated with substantially elevated future economic attainment, whether the latter is measured by earnings, wages, occupational status, or the receipt of fringe benefits. These results are robust across a variety of specifications and sample selection criteria and strongly suggest that employment plays an important developmental role for students as they approach the end of high school. Interestingly, the economic benefits are obtained despite a small reduction in completed schooling. This suggests that time spent on the job detracts slightly from educational human capital investments but more than compensates for this loss through employment-related experience. Work during the senior grade is associated with particularly large gains for students not continuing on to college, raising the possibility that student employment held shortly before the end of formal education may facilitate the school-to-work transition.

\section{Previous Research}

The effects of high school employment have been widely studied since the late 1970 s. Most frequently, researchers have examined the impact of student work on academic performance as measured by grades, test scores, or school completion rates. Employment probabilities and wages, in the period shortly following the end of formal education. ${ }^{6}$ Samples, time periods, and study methodologies vary widely. The key findings of previous research are summarized in table 1 and briefly discussed below.

There is currently no consensus whether student employment improves or worsens school performance, although the data do suggest that any beneficial effects are maximized at low or intermediate hours of work, while harmful impacts are most likely for heavy job commitments. For example, Barone (1993), Greenberger \& Steinberg (1980), Greenberger, et.

6 Researchers have also studied the effects of youth unemployment on future outcomes (e.g. see Ellwood, 1982 or Smith, 1985). 
al. (1982), Mortimer \& Finch (1986), Steinberg \& Dornbusch (1991), and Steinberg, et. al. (1993) argue that high school employment is associated with lower grade point averages. Conversely, Gade \& Peterson (1980), Lillydahl (1990), Meyer \& Wise (1982), Schill, et. al. (1985), and Turner (1994) detect either no effects or beneficial impacts at moderate work hours. ${ }^{7}$ Interestingly, D'Amico (1984) finds that, despite reducing the amount of time spent on studying and school activities, student employment correlates with higher class rank for white males (with no effect for females or minorities) and elevated rates of school completion and college attendance. This suggests that working students may allocate their time more efficiently than their counterparts.

The results pertaining to employment outcomes are more clearcut. Work during high school is unambiguously associated with elevated rates of future job-holding and increased earnings (D'Amico, 1984; Marsh, 1991; Meyer \& Wise, 1982; Mortimer \& Finch, 1986; Stephenson, 1981; Stern \& Nakata, 1989; and Stevenson, 1978). It less obvious, however, whether these represent permanent benefits or transitory gains which disappear over time. Indeed, some researchers have argued that work by youths improves initial outcomes but reduces human capital investments and so has a negative long-term impact. Virtually all previous studies have focused on the period immediately following school completion, making it difficult to infer lifecycle effects. ${ }^{8}$

Correlations between student employment and future outcomes could result from unobserved confounding factors, rather than being due to any causal effects of the work itself. Weiss (1988) argues that the large earnings premium associated with high school graduation

7 A similar lack of consensus is found in research on employment by college students. For instance Paul (1982) uncovers negative effects of working, Hood, et. al. (1992) find the highest GPAs among students employed 7-14 hours/week, and Ehrenberg \& Sherman (1987) contrast positive effects of on-campus job-holding with negative impacts of off-campus positions. \& Exceptions include Mortimer \& Finch (1986) and Stevenson (1978), who utilize data from the 1960 s and early 1970 s and so provide little information on recent cohorts of students. 
occurs because graduates possess large amounts of unobservable traits he groups under the rubric of "stick-to-itiveness". Using the same analogy, if students with low amounts of "stick-to-itiveness" are relatively likely to work (because they do not like school), than youth employment may be associated with unfavorable future outcomes, even in the absence of a causal effect. ${ }^{9}$ Spurious correlation is likely to be particularly problematic when, as in many studies, only rudimentary controls for observable differences are included. These methodological problems are further aggravated when (nonrepresentative) convenience samples are used or when subsamples are selected in ways which introduce unobserved differences between workers and nonworkers. ${ }^{10}$

\section{Trends in Student Employment}

Concern over student employment stems partly from the belief that this type of work has risen rapidly in recent years. For example, Greenberger \& Steinberg (1986) cite a 65\% increase in the labor force participation rates of 16 and 17 year old school-going males (from $27 \%$ to $44 \%$ ) occurring between 1947 and 1980 . The expansion in job-holding during high school is likely to be overstated by these figures, however, for at least two reasons. First, youth unemployment increased dramatically during this period, which implies larger increases in participation rates than in employment probabilities. ${ }^{11}$ Second, the calculated changes are quite

9 Steinberg \& Dornbusch (1991) and Steinberg, et. al. (1993) provide evidence showing that, compared to nonworkers, employed students had lower grades and educational expectations, spent less time studying, and were less engaged in school even before they started working. Some researchers (e.g. Lillydahl, 1990, Meyer \& Wise, 1982) have used multi-equation models or analysis of the time structure of residuals in an effort to separate causation from correlation. These attempts have met with limited success.

10 For example, Steinberg et. al.'s (1982) influential longitudinal study included 176 youths from four Orange County California high schools. This represented $5.7 \%$ of the original (nonrepresentive) sample of students present on two testing days at each school, with potential biases introduced at each stage in the sampling process (e.g. the exclusion of students away from school on the testing days biases the sample against individuals with high rates of absenteeism and the deletion of persons holding jobs prior to but not at the final survey date eliminates students with histories of unstable employment).

11 The unemployment rates of $16-19$ year old males rose from $9.8 \%$ in 1948 to $18.3 \%$ in 1980 
sensitive to the endpoints chosen. Thus, the increase in participation was less than half as large (rising from $37 \%$ to $44 \%$ ) between 1950 and 1980 as when the initial year is 1947 and barely changed at all between 1950 and $1970 .^{12}$

Unpublished Current Population Survey data on the employment-to-population (EP) ratios of 16 to 18 year students are displayed in table 2 . Prior to 1989 , individuals were classified according to their major activity (i.e. "school" vs. "other"). In 1989, the Bureau of Labor Statistics began separately reporting EP ratios by school enrollment status. Since students with heavy work commitments, who consider employment (rather than school) to be their major activity, will be excluded from the pre-1989 statistics, the reported ratios should increase beginning in 1989. Economic conditions were similar in 1968, 1978, and 1988. By contrast, EP ratios are likely to be depressed by the slack economic conditions of 1992 .

The employment-to-population ratios of 16 to 18 year olds with school as a major activity rose slightly between 1968 and 1978 (from $28 \%$ to $30 \%$ ), with large increases for girls and little change for boys. By contrast, there was no growth in job-holding for the decade ending in 1988, as a small contraction in male employment (from $31 \%$ to $29 \%$ ) more than offset marginal increases for females. The fraction of working students is shown to rise by 7 percentage points between 1988 and 1989 (from 30\% to 37\%), reflecting the underestimate of EP ratios in the earlier years, due to the exclusion of enrolled youths not considering school to

(Economic Report of the President, 1992, p. 340).

12 The Current Population Survey may underestimate the level of youth work involvement because the information is typically provided by parents, who systematically understate their children's labor force attachments (Freeman \& Medoff, 1982). Much of the difference between self-reports and proxy-responses relates to casual jobs (e.g. baby-sitting or lawnmowing), which are reported as employment by the youth but not by the parent (Flaim, 1982). Discrepancies between CPS and other survey data often result from differences in what is being measured. For example, much employment information in the High School and Beyond survey refers to the current or most recent job. Thus, many researchers (e.g. Marsh, 1991) report zero hours of work only for those students who have not held jobs at any point during the survey year. This overstates the fraction employed at a given point in time. 
be their major activity. Even more striking, is the large cyclical variability. Between 1989 and the 1992 recession year, the EP ratios of $16-18$ year olds declined from $37 \%$ to $31 \%$. To summarize, the frequency of student job-holding has changed little since the middle 1970s, with any time trend being dwarfed by cyclical fluctuations. This suggests that concerns over rapidly rising employment levels of high school students may be exaggerated.

\section{Data}

This study uses data from the NLSY, a sample of persons aged 14 through 21 on January 1, 1979. Respondents have been interviewed annually since 1979 and information through the 1991 interview is used below. The subsample analyzed is restricted to respondents who: 1) were high school freshman or sophomores in 1979,2$)$ remained enrolled in school through at least the interview date of their senior year (two years if a sophomore in 1979 and three years if a freshman), and 3) were members of the nationally representative sample of noninstitutionalized civilian youths. ${ }^{13}$ These restrictions yield a sample size of 1,149 (588 males and 561 females), 1,067 (545 men and 522 women) of whom were interviewed in 1991 -- a continuation rate of $93 \%$.

The NLSY has several advantages for studying high school employment. First, it is the only survey which has followed a recent cohort of students for a sufficient time period to allow analysis of the long-term effects of working. Second, it contains unusually rich information on background variables which may jointly influence the decision to obtain student employment and subsequent economic attainment. Third, it includes retrospective data on job-holding, including a separate work history file with weekly information on employment status.

13 The NLSY also includes supplemental samples of minority and economically disadvantaged white youths and of 17-21 year olds in the military on September 30, 1978. See Center for Human Resources Research (1992) for further information on the NLSY. 
Two types of information on high school employment are utilized below. The first are questions indicating hours worked during the week prior to the survey date (hereafter referred to as the reference or interview week) of the respondent's sophomore, junior, and senior year of high school. Second, the work history file is used to construct measures of average work intensity during the junior and senior academic years and the preceding summers. ${ }^{14}$ By averaging over multiple weeks, the latter data has the advantage of smoothing transitory variations in employment. On the other hand, individuals may more reliably report work hours for the preceding week than for periods up to a year prior to the survey date. Thus, it is not immediately obvious which employment measure is preferable.

The primary outcome considered is annual earnings from "wages, salary, commissions, or tips... before deductions for taxes or anything else". Earnings are then decomposed into wage rates and employment levels, with the former calculated as total earnings divided by hours or weeks employed. Three additional measures of economic attainment are also analyzed. The first is the Duncan Socioeconomic Index, a widely used measure of occupational status, is included to capture potential differences in occupational attainment not yet reflected by the relative incomes of persons in their middle to late twenties. ${ }^{15}$ The second and third indicate whether group health insurance and retirement benefits (hereafter referred to as pensions) are provided by the current or most recent employer. The dependent variables are averaged over the 3 year period 1988 through 1990, which is 6 to 9 years after the scheduled date of high school graduation. Using information for multiple years dampens the

14 Academic year hours were measured over a 26 week period during October, November, February, March, April, and May. This time frame was chosen to eliminate potentially atypical employment levels occurring during school weeks immediately surrounding the summer and holiday seasons. Information on summer employment was for an 8 week period starting with the week which includes July 1 of the given year. Complete work histories were unavailable for 14 and 15 year olds, which prevented construction of academic year hours for sophomores.

15 See Duncan (1961) for information on the Duncan index and Mutchler \& Poston (1983) for a critique of it. 
effects of temporary fluctuations and reduces the number of observations lost due to missing data. $^{16}$

The econometric analysis includes two sets of supplemental covariates. The first are standard demographic variables indicating ethnic status (black, Hispanic, white), sex, marital status (single vs. currently married), geographic region (northeast, northcentral, south, west), residence in an SMSA and in an urban area, local unemployment rates $(<3 \%, 3-6 \%, 6-9 \%$, $9-12 \%,>12 \%$ ), and high school class at the 1979 survey date (freshman vs. sophomore). Schooling is excluded because student employment may have a strong impact on the level of education, in which case the latter is endogenous. This is directly tested for by examining the relationship between student work hours and the highest grade completed. Results are also separately reported for subsamples stratified by educational attainment.

The second set of attributes includes potentially important characteristics for which data have typically been unavailable to previous researchers. These consist of dichotomous variables indicating whether the respondent and his/her parents are foreign born (three covariates), whether a foreign language was spoken at home, parent's educational attainment (high school dropout, high school graduate, college graduate), if magazines, newspapers, or library cards were in the home at age 14 (three variables), if the respondent considered school boring, unsafe, or was very dissatisfied with it, school type (public vs. private), whether he/she had smoked cigarettes or used drugs (marijuana or hashish) by the sophomore year of high school (two regressors), and religion (Catholic, Jewish, Baptist, other). Also included are continuous measures of expected years of education, the number of siblings, (log of) family incomes, and the score received on the Armed Forces Qualifications Test (AFQT). ${ }^{17}$

${ }^{16}$ If data were missing for a single year, averaging was done over the remaining two years. 17 Family income is averaged over the student's sophomore through senior years of high school, the AFQT score determined in 1981, information on the age of first cigarette and drug use obtained in 1984; and time-varying regressors are evaluated contemporaneously with the 
Sample averages of key variables are presented in table 3 and are self-explanatory.

Column a) displays means for all respondents; column b) is restricted to persons interviewed in 1991. Importantly, individuals remaining in the sample through 1991 have virtually identical characteristics to the full sample, suggesting that attrition occurs fairly randomly. ${ }^{18}$

\section{High School Employment and Economic Outcomes}

Descriptive information on high school work hours is provided in table 4. Column (a) again refers to the full sample and column (b) to persons interviewed in 1991 . The first panel displays data on work hours in the reference week; the second presents corresponding information from the work history file on academic year and summer employment. Employment rates are marginally higher for individuals remaining in the sample throughout the period of investigation but, since there is again little evidence of attrition bias, analysis in the remainder of the paper is restricted to the 1067 respondents continuing in the sample through 1991 .

Work experience rises steadily through the high school years. $28 \%$ of sophomores are employed in the interview week, compared to $43 \%$ of juniors and $51 \%$ of seniors. Given the large fraction of nonemployed students, average weekly work commitments are modest, rising from 3 hours for sophomores to 10 hours for seniors. Conditional upon employment, sophomores, juniors, and seniors work an average of 12,16 , and 19 hours per week respectively. Only $3 \%$ of sophomores, $10 \%$ of juniors, and $19 \%$ of seniors work more than 20 hours in the reference week and just $1 \%, 3 \%$, and $5 \%$ are employed over 30 hours. Thus, only

outcome variables. All of the other covariates refer to the 1979 interview date.

18 Stratifying by employment status reveals that working students are relatively often white, male, smokers, and from advantaged backgrounds (proxied by parent's education and the presence of magazines, newspapers, and library cards in the household). There are no consistent differences across the type of school, highest grade expected, or school attitudes but employed students do have higher AFQT scores. Baptists and students in homes where a foreign language is spoken work relatively infrequently, Catholics disproportionately often. 
a small fraction of students have the heavy job commitments which have raised particular concern in previous research.

Average work hours, over the 26 week academic year period (shown in the lower panel of the table), exceed those for the interview week by 1 hour for juniors ( 8.0 vs. 6.7 hours) and almost 3 hours for seniors ( 12.3 hours vs. 9.6 hours). Since there is no reason to expect hours in any given week to differ systematically from those during a longer period, the disparity is probably due to misreporting of the latter. Conversely, the percentage of weeks worked during the academic year corresponds closely to the employment probabilities for the reference week ( $42.6 \%$ vs. $43.3 \%$ for juniors and $52.3 \%$ vs. $50.8 \%$ for seniors). The combination of these results suggests that work hours are overstated, in the retrospective data, in weeks when respondents are employed. ${ }^{19}$ In light of this, interview week employment hours receive primary attention below.

Employment experience is the norm for high school students. Almost two-thirds of juniors and three-quarters of seniors hold jobs at some point during the 26 week academic year observation period. Employment hours are higher in the summer than during the academic year but the differences are relatively small, suggesting that a large number of students continue their school year employment through the summer and vice versa.

Whites and males work more than nonwhites and females. The gender differential in reference week work hours is $57 \%$ for sophomores (4.1 vs. 2.6 ), $43 \%$ for juniors ( 7.9 vs. 5.5 ), and $12 \%$ for seniors ( 10.1 vs. 9.0 ). White sophomores work $40 \%$ more hours than their minority peers ( 3.5 vs. 2.5 ), with still larger $74 \%$ and $54 \%$ differentials for juniors ( 7.3 vs. 4.2 ) and seniors (10.2 vs. 6.6). Conditional upon holding jobs, however, there no evidence of

19 This is consistent with other research indicating that employment hours are inflated in retrospective data. For instance, in the Panel Study of Income Dynamics validation study, respondents claimed to have worked $10 \%$ to $12 \%$ more hours during the previous year than were indicated by company records (Duncan \& Hill, 1985). 
greater hours for whites. ${ }^{20}$ This suggests that the racial disparities result from differences in opportunities rather than tastes and, if student employment is beneficial, may provide one reason why minorities receive relatively low pay later in life.

High school students who work generally have higher levels of future economic attainment than those who do not. This correlation holds across a variety of outcome measures, typically increases with grade level, is more pronounced for academic year than reference week employment, and is strongest when considering earnings (see table 5). For example, sophomores working more than 20 hours in the interview week earn $9 \%$ more than their nonworking counterparts 6 to 9 years later, compared with differentials of $31 \%$ and $35 \%$ for juniors and seniors. Individuals not employed at any point during the academic year do even worse -- their peers averaging 20 hours of work weekly in the junior and senior grades earn $39 \%$ and $55 \%$ more annually during the $1988-90$ period. These findings provide a first indication that high school employment has favorable impacts on future outcomes.

\section{Econometric Estimates}

The positive relationship between student employment and subsequent labor market attainment could result from confounding factors, rather than actually being caused by youth work experience. For example, persons with advantaged backgrounds may have superior access to jobs both in school and after graduation. If so, socioeconomic differences, rather than high school employment, may explain the disparity in economic achievement. Regression analysis is used below to examine whether the relationship persists after controlling for observable characteristics.

The basic equation estimated is:

20 A table detailing these results is available upon request. D'Amico (1984); Gade \& Peterson (1980); Michael \& Tuma (1984); and Steinberg \& Dornbusch (1991) describe similar gender differences in student employment. Steele (1991) also finds that whites more often work than nonwhites but with no differences in hours conditional on employment. 


$$
Y_{1}=X_{i} \beta+\gamma H_{1}+\delta H_{1}^{2}+\varepsilon_{i}
$$

where $Y_{i}$ is the outcome for individual $i, X$ a set of covariates, $H$ a vector of high school work hours, and $\varepsilon$ the regression disturbance. Quadratic terms are included to allow for nonlinear effects of student employment. The predicted effect of working $\mathrm{H}$ hours (compared to nonworkers) is $\hat{\gamma} \mathrm{H}+\hat{\delta} \mathrm{H}^{2}$, for $\hat{\gamma}$ and $\hat{\delta}$ the regression coefficients obtained from (1). Probability values ( $p$-values) for the hypothesis that $\hat{\gamma}$ and $\hat{\delta}$ are jointly equal to zero are also reported. These are obtained from $F$ or likelihood ratio tests, depending upon whether the estimates are by ordinary least squares (OLS) or using maximum likelihood techniques.

\subsection{Earnings Equations}

Table 6 presents coefficients on work hours and hours squared for various specifications of equation (1), estimated by OLS. Column (a) displays the results of models which separately control for employment hours in a single high school year (i.e. the first panel reports coefficients from three regressions) and include no other covariates. Column (b) combines work experience in the three high school grades into a single equation and again excludes other regressors. Column (c) adds controls for the respondent's race, sex, marital status, geographic region, urbanicity, residence in an SMSA, and high school grade in 1979. The full set of attributes (described in section 4) are included in columns (d) and (e), with the difference between the two being that only (e) contains the AFQT score. ${ }^{21}$ Thus, more characteristics are held constant when moving from left to right of the table. To the extent that the association between high school employment and future incomes is due to confounding factors, we expect the hours coefficients to decline (in absolute value) as covariates are added.

21 The AFQT score is included separately since it may be endogenous. (It is measured in 1981 and therefore could be affected by sophomore and junior year employment.) Reference week employment hours in the sophomore year are also included in the bottom panel, since a corresponding academic year variable can not be constructed from the work history file. 
Work hours during the senior year of high school are positively and strongly correlated with future incomes, even when holding constant an unusually large variety of observables. Indeed, once a basic set of regressors is controlled for (column c), additional explanatory variables have little impact on the estimated effect of student employment. For example, working 10 hours during the senior year reference week is predicted to raise future earnings by $16 \%$ in specification (c), versus $14 \%$ in model (e). The coefficients on senior grade employment are always highly significant.

Conversely, there is no evidence of statistically significant employment effects for sophomores and juniors, once senior work hours are controlled for. The junior year coefficients are positive and significant when nothing else is held constant (column a) but become statistically insignificant with the addition of regressors for senior hours (column b). ${ }^{22}$ The inclusion of individual and background characteristics further reduces the predicted impact of working in the sophomore and junior grades and they never approach statistical significance (columns $\mathrm{c}$ through e). ${ }^{23}$ The remainder of the paper presents results using the extended set of characteristics controlled for in column (e).

The robustness of the predicted impact of senior year employment to changes in specifications and samples is next tested for, with results displayed in table 7. For comparison, column (a) repeats the findings from specification (e) of table 6 . Columns (b) and (c) exploit additional information available in the work history file -- model (b) adds controls for work hours during the summer between the junior and senior year, in order to compare the relative returns

22 This is due to a moderately high correlation of work hours across grades. The correlation between sophomore and junior, junior and senior, and sophomore and senior work hours, respectively, are $0.319,0.447$, and 0.236 .

${ }^{23}$ Coefficients on the other covariates generally conform to our expectations. In particular, subsequent earnings are relatively high for whites, men, persons in areas with low local unemployment rates, those with high educational expectations, and with above average family incomes (see table A.1). 
to academic year and summer employment; specification (c) holds constant the number of weeks the student is employed during the academic year, instead of the number of hours worked per week. Finally, columns (d) and (e) provide separate estimates for males and females.

The finding that senior work hours are positively correlated with future earnings, but with no statistically discernible impact for sophomore and junior employment, is robust across specifications and samples. Interestingly, column (b) suggests that school year employment has a bigger payoff than positions held during the summer. This is surprising since summer work is less likely to divert time away from educational pursuits. It is possible, however, that the two types of employment are qualitatively different. Moreover, school year jobs may require students to develop time management skills to a greater extent than do summer positions. ${ }^{24}$ Column (c) implies that there continues to be a benefit to senior year employment when considering weeks worked, rather than hours per week, and illustrates the need for future research distinguishing between these two effects. Columns (d) and (e) suggest that the returns to job-holding by high school seniors are initially larger but exhibit greater diminishing returns for girls than boys. Small sample sizes imply that these gender differences should be interpreted cautiously.

\subsection{Differences by Educational Status}

A question raised by the econometric estimates is why student employment is beneficial during the senior year of high school while yielding little or no corresponding payoff in the sophomore or junior grades. One plausible hypothesis is that working offers advantages which, although substantial, depreciate rapidly if not quickly utilized. Most directly, some employed

24 Multicollinearity between summer and academic year employment makes it difficult to separately identify the two effects. The correlation between work hours in the junior (senior) year and during the following (preceding) summer is $0.452(0.419)$. 
seniors may be able to continue with the same company after leaving high school.

Alternatively, employers may believe that job-holding during the senior year signals a strong work ethic or provides skills useful to the firm. Thus, working seniors may have an easier school-to-work transition than their counterparts who do not hold jobs. This could translate into long-term benefits if initial (post-school) employment experiences lead to more favorable future opportunities. Conversely, the benefits of holding jobs in the senior grade are likely to be smaller for individuals attending college, since this employment occurs several years before the completion of formal education.

As an informal test of this hypothesis, respondents without university educations are compared to those completing one or more years of college. The former group is expected to contain a relatively large proportion of individuals making immediate transitions into the workforce, after high school, for whom senior year employment is hypothesized to confer the largest benefits.

The benefits of working during the reference week of the senior year are roughly twice as large for persons not going to college as for those who do attend (see the top panel of table 8). For example, working 10 hours in the interview week is predicted to raise future earnings by $21 \%$ for the former group versus a statistically insignificant $9 \%$ for the latter. The effects of sophomore or junior year employment are again always statistically insignificant. Broadly consistent results are obtained for academic year employment (shown in the lower panel of the table). In particular, work in excess of 12 hours per week, in the senior year, is associated with larger increases in future earnings for noncollege educated persons than for those attending college. The work history data also hint at benefits of light work commitments for college-bound seniors and high school juniors not continuing on to university. 


\subsection{Selectivity Bias}

The regression analysis controls for a broader set of covariates than has typically been available to previous researchers. This section presents two additional types of information pertaining to the selection process into high school employment. First, econometric techniques are employed in an attempt to determine the nature of any selectivity bias. Although the precision of the resulting estimates is quite low, these methods provide no indication that the predicted effect of senior year employment is spurious. The second approach involves limiting the analysis to persons with relatively homogeneous future work experiences. This reduces the effects of unobserved heterogeneity, to the extent that the latter translate into differences in employment levels throughout the lifecycle. The effect of working in the senior year remains significant, although declining somewhat in size.

Results of these efforts are summarized in table 9 . For purposes of brevity, all remaining tables focus on reference week work hours in the senior grade and provide separate estimates for the two educational groups. ${ }^{25}$ Column (a) repeats the OLS estimates previously obtained using the comprehensive set of covariates (i.e. specification e in table 6). Column (b) shows results from a "treatment-effects" model where the "treatment" is the choice of whether or not to work in the senior year. In this case, a probit equation is first estimated, with the dependent variable equal to $1(0)$ for respondents working positive hours (not working) in the senior year of high school. The inverse Mills ratio from the probit is then included as an additional covariate in the second-stage earnings equation. ${ }^{26}$ The Mills coefficient indicates the

25 The estimated effects of sophomore and junior grade employment are never statistically significant. As discussed above, results using the work history data are viewed as less reliable due to biases in retrospective reporting of employment hours.

${ }^{26}$ The inverse Mills ratio is $\phi / \Phi(-\phi /(1-\Phi))$ for respondents who do (do not) work in the senior year, where $\phi$ and $\Phi$ are the standard normal density and distribution functions, evaluated at the inner-product of probit coefficients and individual attributes. It is typically difficult to identify this type of model because it is hard to select covariates which can justifiably be included in the probit equation but excluded from the second-stage earnings regression. In this case, it is 
selection effect into senior year employment, with a significantly positive (negative) value implying that estimates from reduced form models (which do not control for endogenous selection) are upwards (downwards) biased. ${ }^{27}$ Column (c) displays a set of corresponding instrumental variable (IV) estimates. As in the treatment-effects specification, geographic characteristics in the senior year of high school serve to identify the models. Finally, columns (d) and (e) provide OLS estimates for respondents averaging at least 1000 hours (column d) and 26 weeks (column e) of employment annually, over the $1988-90$ period. Thus, these subsamples consist of a relatively homogeneous group of highly work motivated individuals.

The econometric techniques of correcting for selection bias meet with limited success. In particular, standard errors increase substantially for the treatment-effects model, as compared to the OLS estimates, and explode in the IV specification. For example, in the top panel of the table, the standard error on senior work hours is $82 \%$ higher in column (b) than in column (a) and almost forty times larger in (column c). Given these large standard errors, the senior year employment effect is measure very imprecisely. ${ }^{28}$ Nonetheless, the coefficients are

assumed that geographic characteristics (local unemployment rates, region of the country, SMSA and urbanicity) during the senior year affect student employment (and so are included in the probit) but have no impact on future outcomes (and so are excluded from the earnings equation) while the reverse is true for geographic conditions averaged over the 1988-90 period. 27 See Greene (1993, pp. 713-4) for further discussion of the treatment-effects model.

${ }^{28}$ The variables used for identification appear valid. As a group, they are jointly significant (at the .05 level) in the first-stage equation of the treatment-effects and IV model, for the full sample and for respondents not attending college (although not for the group with university educations). The instruments also easily pass Newey's (1985) test for exogeneity based on overidentification restrictions. The test statistic, obtained by multiplying the sample size by the uncentered $R^{2}$ of an equation regressing the residuals of the structural model of interest on all the exogenous variables, has a chi-squared distribution with degrees of freedom equal to the difference between the number of instruments and endogenous variables. For the full sample, the estimated chi-squared statistic is 116 , with two degrees of freedom, compared to a critical chi-squared statistic (at the .05 level) of 5.99. The chi-squared statistic for the subsample without (with) a college education is .745 (.065). Instead, the structural estimates have high standard errors because of the relatively weak predictive power of the instruments. For instance, the $\mathrm{R}^{2}$ of a first-stage equation on senior year employment hours rises from .072 to .095 when the senior year geographic characteristics are added to the model, leaving most of the variation unexplained. 
larger than for the corresponding OLS estimates in 5 of 6 cases, suggesting that the reduced form models are more likely to understate than overestimate the effect of student employment.

The return to senior year job-holding does decline somewhat when restricting the sample to persons with substantial future work experience. Statistically significant positive effects continue to be observed for the full sample, however, and for noncollege educated respondents working 1000 hours or more per year (see columns $d$ and e). For example, the difference associated with 10 hours of reference week employment is $11 \%(9 \%)$ among those working at least 1000 hours (26 weeks) annually between 1988 and 1990 , as compared to $14 \%$ for all respondents (column a). Student work experience is likely to improve subsequent economic attainment partly by increasing future employment levels. Deleting persons with sporadic work experience eliminates a large portion of this effect and so estimates for the subsamples in columns (d) and (e) probably understate the favorable effect of job-holding by high school seniors. The continued evidence of positive impacts therefore furnishes powerful evidence that work by students provides genuine benefits.

There are at least three additional reasons to doubt that selection bias explains the advantages associated with senior year employment. First, the estimated impact falls only slightly when moving from a relatively parsimonious specification to one which controls for a broad array of potentially important covariates (e.g. from column c to e of table 6). Second, if high school employment is disproportionately obtained by persons with favorable unobserved characteristics, it should be associated with high levels of academic achievement, rather than the opposite result observed by some researchers. Third, and most important, there is no reason why the effects of confounding should be limited to job-holding in the senior grade. For instance, if differences in unobserved motivation are of key importance, stronger effects might 
be expected for sophomore or junior employment, since work is less common in these grades and therefore presumably occurs among a more selected group.

\subsection{Other Measures of Economic Attainment}

The effect of senior year job-holding on (log) wages and employment levels is detailed in table 10. Since annual work hours are left-censored at 0 and weeks employed are left and right-censored at 0 and 52, respectively, OLS is inappropriate for these outcomes and tobit models are estimated. ${ }^{29}$ Employed high school seniors earn higher wages and work more in the future than their nonemployed counterparts. For example, working 10 hours per week in the last year of high school is associated with a $5 \%$ differential in hourly wages and a more than 100 hour per year increase in employment, over the $1988-90$ period (columns $b$ and $d$ ). The difference in hours and weeks worked is highly significant for all groups. The wage effect is significant at the ten percent level for the full sample and for noncollege bound respondents but does not approach statistical significance for those with college educations. Thus, 10 hours of work in the senior grade is predicted to raise future hourly wages by $8 \%$ overall and $11 \%$ for individuals not attending college, versus just $4 \%$ for those who do go to university.

Respondents lacking high school work experience could receive relatively low pay because they have made substantial investments in formal education which have not begun to pay off by their middle to late twenties. Alternatively, nonworking students could disproportionately choose careers offering low pay but which provide compensating differentials in the form of fringe benefits. To explore these possibilities, we next consider the relationship between student employment and four supplementary outcomes. The Duncan score, a commonly used index of occupational prestige, is the dependent variable in column (a) of table

29 Columns (c) and (d) of the table show tobit coefficients. The effects of marginal changes in work hours can be estimated by multiplying the relevant coefficients by $\Phi($.), the predicted percentage of noncensored observations. 
11. Columns (b) and (c) indicate whether the employer provides two important fringe benefits: health insurance and pension coverage. Since the latter variables are trichotomous, indicating whether the benefit is provided in none, some, or all of the 3 years, ordered probit models are estimated. Finally, column (d) examines educational attainment, measured as the highest grade completed by the 1991 survey date.

Full sample results for the Duncan index and the two fringe benefits are entirely analogous to those for future incomes. Employment in the senior year is positively and statistically significantly related to all three outcomes (see the top panel of the table). This occurs despite a small negative impact of job-holding on education levels. For instance, 10 hours of reference week employment is associated with 8 and 9 percentage point increases in the probability of subsequently receiving group health insurance and pension benefits but with a .07 year reduction in educational attainment. Thus, it appears that working seniors sacrifice a small amount of formal education in exchange for substantially larger job-related investments in human capital. This result is consistent with previous research indicating that youth employment has ambiguous impacts on educational achievement but consistently positive effects on job-related outcomes.

Work hours are also positively related to occupational attainment, as measured by the Duncan Score, for noncollege-bound respondents, whereas there is no statistically significant relationship for those completing one or more years of higher education. Interestingly, a stronger association between moderate levels of student employment and future receipt of employer health insurance or pension benefits is obtained for university educated persons than for respondents with less schooling (see the bottom two panels of table 11). Further research is needed to verify and explain these differences. 


\subsection{Predicted Effects of Senior Year Employment}

The differences in five labor market outcomes associated with various amounts of senior year employment are summarized in table 12. Predictions are obtained from equations which control for the full set of covariates (i.e. specification e of table 6). The first three columns show results for log earnings, log hourly wages, and the Duncan score. The last two columns refer to probabilities of obtaining employer-provided health insurance and pension coverage at all three of the 1988 through 1990 survey dates. The fourth row of each panel shows the number of hours of student employment at which the specified outcome is predicted to reach a maximum.

Compared to nonworking seniors, 10 hours of employment in the reference week is associated with $14 \%$ greater future earnings, an $8 \%$ rise in hourly wages, a 2.8 point higher Duncan Score, and 8 and 9 percentage point increases in the probability of obtaining group health insurance and pension coverage respectively. The predicted gains are substantially larger for those working 20 hours per week - $22 \%, 11 \%$, and 4.1 points for earnings, hourly wages, and the Duncan score and more than 11 percentage points for each of the two fringe benefits. Finally, the expected benefits are maximized at between 19 and 27 hours per week, implying that senior grade employment has substantial but diminishing returns.

As discussed, the returns to senior year work experience are greater, by most measures, for noncollege educated respondents than for those finishing one or more years of university. For instance, the premiums associated with working 20 hours in the reference week are $35 \%, 18 \%$, and 6.3 points for annual earnings, hourly wages, and Duncan scores among the former group, versus $12 \%, 3 \%$, and 2.3 points among the latter. There is also less evidence of diminishing returns to student employment for respondents whose education ends with high school. Maximum benefits are predicted for this group at 29, 58, and 34 hours of work in the reference week, respectively, as compared to 19,13, and 17 hours for those 
attending college. This provides further evidence of the benefits of making an early and substantial start on the school-to-work transition for students not continuing on to university.

\section{Conclusion}

Much of the alarm that employment hinders the long-term development of high school students has been based on analyses of nonrepresentative samples and using methods which are unlikely to account for the selection process into student job-holding. The concerns have been magnified by a belief that work by in-school youths has rapidly increased since the end of World War II. Actually, this trend is less pronounced than is often realized and appears to have ended by the late 1970s, with subsequent reductions in the employment-to-population ratios of some groups (e.g. 16-18 year old boys). Moreover, relatively few students are employed the long hours causing particular consternation.

This study uses data from the National Longitudinal Survey of Youth to examine the effects of student employment on future labor market outcomes. Contrary to some previous research, the investigation fails to uncover any evidence of harmful effects of working during high school. Instead, jobs held during the senior year yield substantial and lasting benefits. For example, seniors employed 20 hours per week are expected to earn approximately $21 \%$ more annually, 6 to 9 years later, and to receive $11 \%$ higher hourly wages than their counterparts who do not work. They are also more likely to receive pensions and health insurance from their employers and work in higher status occupations.

The favorable effects of high school employment persist after controlling for a comprehensive set of background characteristics and are robust across a variety of specifications, samples, and estimation techniques. The gains in future incomes associated with working in the senior year are substantially greater for noncollege-bound students than for those completing one or more years of higher education. This suggests that the benefits of 
student job-holding depreciate rapidly, unless they immediately precede the school-to-work transition, and helps to explain the much smaller returns to employment in the sophomore and junior grades.

Several caveats are worth noting. First, controls for a still broader set of covariates could reduce the advantages associated with employment by high school seniors. Second, this study focuses exclusively on measurable economic outcomes. Third, the analysis is restricted to individuals remaining in school through the normal age of high school graduation. Finally, although this investigation covers a longer time period than previous research, there may be deleterious impacts of student job-holding which do not show up until later in life.

While these qualifications imply that the conclusions of this study should be interpreted cautiously, it is doubtful that any of them account for the key finding that benefits are associated with senior year employment. The characteristics controlled for in this analysis are unusually comprehensive and there is little evidence that the addition of covariates, beyond the basic set available to previous researchers, substantially changes the results. Furthermore, the findings are unlikely to be explained by spurious correlation between senior grade job-holding and important excluded characteristics, since most such factors would also be associated with employment in the sophomore and junior years. For example, if unobserved differences in socioeconomic status increase both the probability of working in high school and the level of future economic attainment, employment in all three grades would be positively correlated with subsequent labor market status. Instead, strong benefits are observed only for working seniors.

Deleterious effects of student employment on the social development of adolescents are likely to be at least partially manifested in future labor market outcomes. The positive economic impacts of working therefore suggests that these problems either do not occur, are transitory in 
nature, or are more than compensated for by beneficial investments in human capital. Although the analysis does indicate that job-holding in the senior year reduces educational attainment, the predicted effect is small -- working 10 hours per week is associated with a reduction in schooling of less than three weeks. There could be a larger impact on high school completion rates but this possibility is belied by the lack of evidence that work in either the sophomore or junior year has an impact on the highest grade completed (among those remaining in school through their senior year) or on any of the other outcome variables.

The likelihood that negative effects of high school work experience do not show up until later ages than those studied is reduced by the strong positive correlation between senior year employment and the Duncan occupational index. Working 20 hours per week in the senior grade is associated with a 4 point increase in the Duncan Score for the full sample and a more than 6 point rise among respondents not attending college..$^{30}$ To the extent that occupational attachments are established by the middle to late twenties, the Duncan index should reveal differences in status which will be reflected in earnings at later ages.

This investigation indicates that student employment raises future productivity through the skills, knowledge, work habits, and experience provided on-the-job by far more than it detracts from educational human capital investments. Evidence from time-use studies suggests that this occurs because the time spent working reduces leisure pursuits to much greater extent than it decreases school or homework activities. For example, Turner's (1994) analysis of the High School and Beyond Survey illustrates that, in 1980, the average high school senior spent 18 hours per week watching television compared to less than 4 hours on homework. He further estimates that working 20 hours per week reduces homework by just $3.2 \%$ (7.2 minutes per week), while decreasing television time by $19.9 \%$ ( 3.6 hours per week). ${ }^{31}$

30 For comparison, the Duncan score of a welder exceeds that of an assembler by 6 points. 31 Students employed 1 to 16 hours per week are actually predicted to spend more time on 
This suggests that the benefits of student employment exceed the costs because the latter are typically so low. It also implies that job-holding may have less favorable effects for students who would (otherwise) spend relatively large amounts of time on school work. This may help to explain the lower returns for respondents continuing on to college.

Additional research on the benefits and costs of high school work experience is needed. In particular, it is important to better understand the mechanisms by which the employment raises economic attainment, to analyze the role of job characteristics of the positions held by youths enrolled in school, and to examine the nature and sources of demographic group differences in the returns to student employment. Based upon the current state of knowledge, however, concern that work during high school has extremely deleterious consequences appears to be misplaced. A tentative but fairly strong conclusion is that light to moderate work commitments provide important net benefits and so should be encouraged, especially for students approaching the end of high school who are unlikely to enter college.

homework than those who do not work. 


\section{References}

Barone, Frank J. 1993. "The Effects of Part-Time Employment on Academic Performance" NASSP Bulletin, Vol. 77, January, pp. 67-73.

Brooks, William C. 1991. "How to Stop Child Labor Law Abuses" USA Today Magazine, March, pp. $38-40$.

Center for Human Resources Research. 1992. NLS Handbook, 1992. Columbus, OH: The Ohio State University Press.

D'Amico, Ronald. 1984. "Does Employment During High School Impair Academic Progress?" Sociology of Education, Vol. 57, July, pp. 152-64.

D'Amico, Ronald \& Paula Baker. 1984. "The Nature and Consequences of High School Employment" in Paula Baker et. al. (eds.) Pathways to the Future, Vol. 4, Columbus, $\mathrm{OH}$ : Center for Human Resources Research, The Ohio State University, pp. 1-49.

Duncan, Greg J. and Daniel H. Hill. 1985. "An Investigation of the Extent and Consequences of Measurement Error in Labor-economic Survey Data" Journal of Labor Economics, Vol. 3, October, pp. 508-32.

Duncan, Otis D. 1961. "A Socioeconomic Index for All Occupations", in Albert J. Reiss Jr. (ed.) Occupations and Social Status, New York: The Free Press, pp. 109-38.

Economic Report of the President. 1992. Washington, D.C.: U.S. Government Printing Office.

Ehrenberg, Ronald G. \& Daniel R. Sherman. 1987. "Employment While in College, Academic Achievement and Postcollege Outcomes" Journal of Human Resources, Vol. 22, No. 1 (Winter), pp. 1-24.

Ellwood, David T. 1982. "Teenage Unemployment: Permanent Scars or Temporary Blemishes?" in Richard B. Freeman \& David A. Wise (Eds.) The Youth Labor Market Problem: Its Nature, Causes, and Consequences, Chicago, IL: University of Chicago Press, pp. 349-85.

Flaim, Paul O. 1982. "Comment on Why Does the Rate of Youth Labor Force Activity Differ Across Surveys?" in Richard B. Freeman \& David A. Wise (Eds.) The Youth Labor Market Problem: Its Nature, Causes, and Consequences, Chicago, IL: University of Chicago Press, pp. 104-110.

Freeman, Richard B. and James L. Medoff. 1982. "Why Does the Rate of Youth Labor Force Activity Differ Across Surveys?" in Richard B. Freeman \& David A. Wise (Eds.) The Youth Labor Market Problem: Its Nature, Causes, and Consequences, Chicago, IL: University of Chicago Press, pp. 74-104. 
Gade, Eldon \& Lois Peterson. 1980. "A Comparison of Working and Nonworking High School Students on School Performance, Socioeconomic Status, and Self-Esteem" The Vocational Guidance Quarterly, September, pp. 65-9.

Greenberger, Ellen \& Laurence D. Steinberg 1980. "Part-Time Employment of In-School Youths: A Preliminary Assessment of Costs \& Benefits", in U.S. Vice President's Task Force on Youth Employment, A Review of Youth Employment Problems, Programs, and Policies, U.S. Department of Labor, Employment and Training Administration, pp. 1-15.

Greenberger, Ellen, \& Laurence Steinberg. 1986. When Teenagers Work: The Psychological and Social Costs of Adolescent Employment. New York: Basic Books.

Greenberger, Ellen, Laurence D. Steinberg, and Mary Ruggiero. 1982. "A Job is a Job...or is It?" Work and Occupations, Vol. 9, No. 1 (February), pp. 79-96.

Greene, William H. 1993. Econometric Analysis, second edition, New York: Macmillian Publishing Company.

Hood, Albert B., Craig, Andrew, F., \& Ferguson, Bruce, W. 1992. "The Impact of Athletics, Part-time Employment, and Other Academic Activities on Academic Achievement" Journal of College Student Development, Vol. 33, September, pp. 447-53.

Lillydahl, Jane H. 1990. "Academic Achievement and Part-Time Employment of High School Students" Journal of Economic Education, Summer, pp. 307-16

Marsh, Herbert W. 1991. "Employment During High School: Character Building or A Subversion of Academic Goals?" Sociology of Education, Vol. 64, July, pp. 172-89.

Meyer, Robert H. \& David A. Wise. 1982. "High School Preparation and Early Labor Force Experience" in Richard B. Freeman \& David A. Wise (Eds) The Youth Labor Market Problem: Its Nature, Causes, and Consequences, Chicago, IL: University of Chicago Press, pp. 277-341.

Michael, Robert T. \& Nancy Brandon Tuma. 1984. "Youth Employment: Does Life Begin at $16 ? "$ Journal of Labor Economics, Vol. 2, No. 4, pp. 464-76.

Mortimer, Jeylan T. \& Michael D. Finch. 1986. "The Effects of Part-time Work on Adolescent Self-Concept \& Achievement" in K. Borman \& J. Reisman (eds.), Becoming A Worker, Norwood, NJ: Ablex, pp. 66-89.

Mutchler, Jan E. \& Dudley L. Poston Jr. 1983. "Do Females Necessarily Have the Same Occupational Status Scores as Males? A Conceptual and Empirical Examination of the Duncan Socioeconomic Status Index and Nam-Powers Occupational Status Scores" Social Science Research, Vol. 12, pp. 353-62.

National Commission on the Reform of Secondary Education. 1973. The Reform of Secondany Education. New York: McGraw-Hill. 
National Panel on High School and Adolescent Education. 1976. The Education of Adolescents. Washington D.C.: U.S. Government Printing Office.

Nelson, Richard R. 1994. "State Labor Legislation Enacted in 1993" Monthly Labor Review, January, pp. 36-52.

Newey, Whitney K. 1985. "Generalized Method of Moments Specification Testing" Journal of Econometrics, Vol. 29, 229-56.

Paul, Harvey. 1982. "The Impact of Outside Employment on Student Achievement in Macroeconomic Principles" Journal of Economic Education, Summer, pp. 51-56.

President's Science Advisory Committee. 1974. Youth: The Transition to Adulthood. Chicago, IL: University of Chicago Press.

Schill, William J., Rosemarie McCartin, and Katrina Meyer. 1985. "Youth Employment: Its Relationship to Academic and Family Variables" Journal of Vocational Behavior, Vol. 26, pp. 155-63.

Smith, Marvin V. 1985. "Early Labor Market Experiences of Youth and Subsequent Wages" American Journal of Economics and Sociology, Vol. 44, October, pp. 391-400

Steel, Lauri. 1991. "Early Work Experience Among White and Non-White Youths: Implications for Subsequent Enrollment and Employment" Youth and Society, Vol. 22, No. 4, pp. 419-47.

Steinberg, Laurence, Suzanne Fegley, and Sanford M. Dornbusch. 1993. "Negative Impact of Part-Time Work on Adolescent Adjustment: Evidence From a Longitudinal Study" Developmental Psychology, Vol. 29, No. 2, pp. 171-180.

Steinberg, Laurence and Sanford M. Dornbusch. 1991. "Negative Correlates of Part-Time Employment During Adolescence: Replication and Elaboration" Developmental Psychology, Vol. 27, No. 2, pp. 304-313.

Steinberg, Laurence D., Ellen Greenberger, Laurie Garduque, and Sharon McAuliffe. 1982. "High School Students and the Labor Force: Some Costs \& Benefits to Schooling \& Learning" Education, Evaluation, and Policy Analysis, Vol. 4, No. 3, pp. 373-82.

Steinberg, Laurence D., Ellen Greenberger, Laurie Garduque, Mary Ruggiero, \& Alan Vaux. 1982. "Effects of Working on Adolescent Development" Developmental Psychology, Vol. 18 , No. 3, pp. 385-95.

Stephenson, Stanley, P. 1981. "In-School Labour Force Status \& Post-School Wage Rates of Young Men" Applied Economics, Vol. 13, pp. 279-302.

Stern, David, Martin McMillion, Charles Hopkins, \& James Stone. 1990. "Work Experience for Students in High School and College" Youth and Society, Vol. 21, No. 3, pp. 355-89. 
Stern, David \& Yoshi-Fumi Nakata. 1989. "Characteristics of High School Students' Paid Jobs and Employment Experience After Graduation" in David A. Stern \& Dorothy Eichorn (eds.) Adolescence and Work: Influences of Social Structure, Labor Markets, \& Culture, Hillsdale, NJ: Lawrence Erlbaum Associates, pp. 189-233.

Stevenson, Wayne. 1978. "The Relationship Between Early Work Experience \& Future Employability" in Arvil V. Adams \& Garth L. Mangum (Eds), The Lingering Crisis of Youth Unemployment, Kalamazoo, MI: W.E. Upjohn Institute for Employment Research, pp. 93-124.

Topel, Robert H. and Michael P. Ward. 1992. "Job Mobility and the Careers of Young Men" Quarterly Journal of Economics, Vol. 107, May, pp. 441-79.

Turner, Mark D. 1994. "The Effects of Part-Time Work on High School Students Academic Achievement", mimeo, University of Maryland.

Tymms, P.B. \& C.T. Fitz-Gibbon. 1992. "The Relationship Between Part-Time Employment and A-level Results" Educational Research, Vol. 34, No. 3, Winter, pp. 193-9.

Weiss, Andrew. 1988. "High School Graduation, Performance, and Wages" Journal of Political Economy, Vol. 96, No. 4, 785-820.

Yeatts, James. 1994. "Which Students Work and Why?", unpublished M.A. thesis, University of North Carolina Greensboro. 


\begin{tabular}{|c|c|c|c|}
\hline Author & Sample & $\begin{array}{l}\text { "Effects" of Employment and } \\
\text { Increased Work Hours }\end{array}$ & Comments \\
\hline $\begin{array}{l}\text { Barone } \\
(1993)\end{array}$ & $\begin{array}{l}2000 \text { students from } 4 \\
\text { upstate New York high } \\
\text { schools. }\end{array}$ & $\begin{array}{l}\text { Slightly lower GPAs, beyond a low } \\
\text { work threshold. }\end{array}$ & $\begin{array}{l}\text { Potentially } \\
\text { nonrepresentative sample, } \\
\text { no covariates. }\end{array}$ \\
\hline $\begin{array}{l}\text { D'Amico } \\
(1984) ; \\
\text { D'Amico \& } \\
\text { Baker } \\
(1984)\end{array}$ & $\begin{array}{l}\text { National Longitudinal } \\
\text { Survey Youth Cohort } \\
\text { (NLSY), 1979-82 } \\
\text { interviews; high school } \\
\text { students (in 1979). }\end{array}$ & $\begin{array}{l}\text { Reduced study time and time spent } \\
\text { in school activities. Positive effects } \\
\text { on class rank for white males, no } \\
\text { impact for other groups. Increased } \\
\text { knowledge of work world for females. } \\
\text { Decreased (increased) educational } \\
\text { levels above (below) } 20 \text { hours/week } \\
\text { of work. Lower unemployment rates } \\
\text { and higher wages in first year out of } \\
\text { high school (for noncollege bound). }\end{array}$ & $\begin{array}{l}\text { Somewhat selected } \\
\text { sample (e.g. class rank } \\
\text { only available for } \\
\text { respondents graduating } \\
\text { high school by January } \\
\text { 1991). }\end{array}$ \\
\hline \begin{tabular}{|l} 
Gade \& \\
Peterson \\
$(1980)$ \\
\end{tabular} & $\begin{array}{l}351 \text { tenth grade students } \\
\text { in two urban high schools } \\
\text { in upper midwest. }\end{array}$ & $\begin{array}{l}\text { Statistically insignificantly higher } \\
\text { grades. }\end{array}$ & $\begin{array}{l}\text { Small, possibly } \\
\text { unrepresentative samples. }\end{array}$ \\
\hline $\begin{array}{l}\text { Greenberger } \\
\text { \& Steinberg } \\
\text { (1980); } \\
\text { Greenberger } \\
\text { et. al. (1982) }\end{array}$ & $\begin{array}{l}531 \text { tenth and eleventh } \\
\text { graders from } 4 \text { Southern } \\
\text { California high schools } \\
\text { working in first jobs or who } \\
\text { had never worked. }\end{array}$ & $\begin{array}{l}\text { Greater absenteeism from school, } \\
\text { lower GPAs, less time studying, } \\
\text { lower educational expectations, more } \\
\text { frequent delinquency, greater } \\
\text { "business knowledge". }\end{array}$ & $\begin{array}{l}\text { Unrepresentative sample, } \\
\text { selection procedure } \\
\text { introduces biases. }\end{array}$ \\
\hline \begin{tabular}{|l} 
Lillydahl \\
(1990)
\end{tabular} & $\begin{array}{l}\text { Juniors and seniors not } \\
\text { attending vocational } \\
\text { schools from } 1987 \\
\text { National Assessment of } \\
\text { Economic Education. } \\
\end{array}$ & $\begin{array}{l}\text { Intermediate work levels }(1-10 \\
\text { hours/week) associated with highest } \\
\text { levels of academic achievement. }\end{array}$ & $\begin{array}{l}\text { Simultaneous equation } \\
\text { model is poorly described; } \\
\text { specifications vary across } \\
\text { outcome measures. }\end{array}$ \\
\hline $\begin{array}{l}\text { Marsh } \\
(1991)\end{array}$ & $\begin{array}{l}\text { High School and Beyond } \\
\text { Survey (HSB), 1980-84 } \\
\text { interviews. }\end{array}$ & $\begin{array}{l}\text { Reduction in a wide variety of } \\
\text { education outcome measures. } \\
\text { Decrease in probability of } \\
\text { unemployment two years after } \\
\text { normal high school graduation date. }\end{array}$ & $\begin{array}{l}\text { Attrition reduces sample } \\
\text { size and could induce bias. } \\
\text { Effects of work hours } \\
\text { assumed to be linear }\end{array}$ \\
\hline \begin{tabular}{|l|} 
Meyer \& \\
Wise (1982)
\end{tabular} & \begin{tabular}{|l|} 
National Longitudinal \\
Survey of the High School \\
Class of 1972, 1972-76 \\
interviews, males only.
\end{tabular} & $\begin{array}{l}\text { Increases in academic performance, } \\
\text { weeks worked, and wage rates. }\end{array}$ & $\begin{array}{l}\text { Relatively good controls for } \\
\text { background } \\
\text { characteristics. }\end{array}$ \\
\hline $\begin{array}{l}\text { Mortimer \& } \\
\text { Finch (1986) }\end{array}$ & $\begin{array}{l}\text { Youth in Transition Study, } \\
1966-74 \text { interviews, tenth } \\
\text { graders (in 1966). }\end{array}$ & $\begin{array}{l}\text { Lower grades, academic } \\
\text { self-esteem, educational, and } \\
\text { occupational aspirations. Higher } \\
1973 \text { earnings and occupational } \\
\text { attainment levels. Stronger effects at } \\
\text { high work hours. }\end{array}$ & $\begin{array}{l}\text { Data available for } 5 \text { years } \\
\text { after normal high school } \\
\text { graduation date. Effects of } \\
\text { dropping out of high school } \\
\text { not adequately accounted } \\
\text { for. }\end{array}$ \\
\hline $\begin{array}{l}\text { Schill, et. al. } \\
(1985)\end{array}$ & $\begin{array}{l}\text { 14-19 year old students in } \\
\text { Washington State taking } \\
\text { classes required for high } \\
\text { school graduation. }\end{array}$ & $\begin{array}{l}\text { Higher GPAs, particularly at } 1-20 \\
\text { hours of work. }\end{array}$ & $\begin{array}{l}\text { No covariates controlled } \\
\text { for. Probable confounding } \\
\text { of unobserved differences } \\
\text { in backgrounds. }\end{array}$ \\
\hline
\end{tabular}


Table 1: (continued)

\begin{tabular}{|c|c|c|c|}
\hline Author & Sample & $\begin{array}{l}\text { "Effects" of Employment and } \\
\text { Increased Work Hours }\end{array}$ & Comments \\
\hline Steel (1991) & \begin{tabular}{|l|} 
NLSY, $1979-81$ interviews, \\
$17-18$ year olds (in 1979).
\end{tabular} & \begin{tabular}{|l|} 
Future school enrollment rates raised \\
(lowered) by moderate (high) work \\
hours for whites. More negative \\
effects for blacks. Subsequent \\
weeks worked increased for whites; \\
no effect for blacks, Hispanics.
\end{tabular} & $\begin{array}{l}\text { Inclusion of out-of-school } \\
\text { youths in sample biases } \\
\text { analysis of future } \\
\text { enrollment rates. } \\
\text { Imprecise estimates for } \\
\text { nonwhites. }\end{array}$ \\
\hline $\begin{array}{l}\text { Stephenson } \\
(1981)\end{array}$ & $\begin{array}{l}\text { National Longitudinal } \\
\text { Survey (NLS) of Young } \\
\text { Men, 1966-71 interviews. }\end{array}$ & $\begin{array}{l}\text { Raises future wages, especially for } \\
\text { full-time employment during high } \\
\text { school. }\end{array}$ & $\begin{array}{l}\text { Wages of nonworkers set } \\
\text { to zero, rather than to } \\
\text { potential earnings levels. } \\
\text { Future wages could reflect } \\
\text { continuation of high school } \\
\text { jobs. }\end{array}$ \\
\hline $\begin{array}{l}\text { Stern \& } \\
\text { Nakata } \\
(1989)\end{array}$ & $\begin{array}{l}\text { NLSY, } 1979-82 \text { interviews, } \\
\text { high school seniors who } \\
\text { graduated high school but } \\
\text { did not directly enroll in } \\
\text { college. }\end{array}$ & \begin{tabular}{|l|} 
Higher hourly earnings and less \\
unemployment after high school \\
graduation, particularly when student \\
employment required complex \\
dealings with people, things, or data.
\end{tabular} & $\begin{array}{l}\text { Relatively few covariates } \\
\text { controlled for. }\end{array}$ \\
\hline $\begin{array}{l}\text { Stevenson } \\
(1978)\end{array}$ & $\begin{array}{l}\text { NLS young men and } \\
\text { young women. } 16-19 \text { year } \\
\text { olds in initial survey year } \\
\text { and followed for } 7 \text { years. }\end{array}$ & $\begin{array}{l}\text { High employment rates and earnings } \\
\text { in later years. }\end{array}$ & $\begin{array}{l}\text { Few covariates controlled } \\
\text { for and some (e.g. labor } \\
\text { market knowledge) may be } \\
\text { endogenous. }\end{array}$ \\
\hline \begin{tabular}{|l|} 
Steinberg \& \\
Dornbusch \\
$(1991) ;$ \\
Steinberg, \\
et. al. (1993)
\end{tabular} & $\begin{array}{l}\text { 10th-12th graders from } 6 \\
\text { high schools in Northern } \\
\text { California and } 3 \text { in } \\
\text { Wisconsin, interviewed in } \\
\text { fall 1987, spring } 1988 \text { (and } \\
1 \text { year later in Steinberg, } \\
\text { et. al.) }\end{array}$ & $\begin{array}{l}\text { No effect for 1-10 hours of work. } \\
\text { Negative effects on a wide variety of } \\
\text { school performance, psychological, } \\
\text { and psychosocial maturity variables } \\
\text { for longer work hours. }\end{array}$ & $\begin{array}{l}\text { Few covariates. Outcomes } \\
\text { assessed up to } 5 \text { months } \\
\text { after employment status } \\
\text { was measured. Potentially } \\
\text { severe selection bias in } \\
\text { longitudinal analysis. }\end{array}$ \\
\hline \begin{tabular}{|l|} 
Steinberg \& \\
Greenberger \\
$(1982)$
\end{tabular} & $\begin{array}{l}\text { Sophomores and juniors in } \\
1979 \text { from four Southern } \\
\text { California high schools } \\
\text { reinterviewed in } 1980 .\end{array}$ & $\begin{array}{l}\text { Greater work orientation; less school } \\
\text { involvement but no difference in } \\
\text { absenteeism or GPAs; more } \\
\text { materialistic attitudes; greater use of } \\
\text { cigarettes and marijuana. }\end{array}$ & $\begin{array}{l}\text { Unrepresentative sample } \\
\text { and selection process } \\
\text { introduces potentially } \\
\text { severe biases of unknown } \\
\text { direction. }\end{array}$ \\
\hline $\begin{array}{l}\text { Turner } \\
(1994)\end{array}$ & $\begin{array}{l}\text { HSB survey, } 1980 \& 1982 \\
\text { interviews. }\end{array}$ & $\begin{array}{l}\text { Positive (negative) effects of } \\
\text { moderate (high) work hours on } \\
\text { grades, test scores, and educational } \\
\text { attainment. Effects reduced when } \\
\text { controls for selection bias are } \\
\text { introduced. Modest reductions in } \\
\text { study time, large decreases in leisure } \\
\text { activities. }\end{array}$ & $\begin{array}{l}\text { Questionable exclusion } \\
\text { restrictions (for selection } \\
\text { bias corrections). } \\
\text { Employment assumed to } \\
\text { affect contemporaneous } \\
\text { grades and test scores. }\end{array}$ \\
\hline $\begin{array}{l}\text { Tymms \& } \\
\text { Fitz-Gibbon } \\
(1992)\end{array}$ & $\begin{array}{l}\text { U.K. students studying for } \\
\text { the A-level exams from } \\
1989 \text { A-level Information } \\
\text { Systems Data Set. }\end{array}$ & $\begin{array}{l}\text { Small negative effect on A-level } \\
\text { grades, particulariy above } 9 \\
\text { hours/week. No impact on study } \\
\text { time. }\end{array}$ & $\begin{array}{l}\text { Few covariates controlled } \\
\text { for. }\end{array}$ \\
\hline
\end{tabular}


Table 2:

Employment-to-Population Ratios of 16-18 Year Old Students in Selected Years

\begin{tabular}{llllll}
\hline Group & 1968 & 1978 & 1988 & 1989 & 1992 \\
& \multicolumn{2}{c}{ (School is Major Activity) } & (Enrolled in School) \\
\hline & & & & & \\
$16-18$ year olds & $27.6 \%$ & $30.4 \%$ & $29.8 \%$ & $37.2 \%$ & $31.2 \%$ \\
Males, 16-18 years old & 32.4 & 31.4 & 29.1 & 36.3 & 30.6 \\
Females, 16-18 years old & 22.5 & 29.3 & 30.6 & 38.0 & 31.9 \\
& $23.5 \%$ & $25.5 \%$ & $23.6 \%$ & $28.8 \%$ & $22.4 \%$ \\
16 year olds & 30.7 & 35.2 & 33.9 & 40.0 & 33.7 \\
17 year olds & 30.0 & 31.6 & 33.3 & 44.3 & 40.2 \\
18 year olds & & & & & \\
\hline
\end{tabular}

Note: Table shows annual average employment-to-population ratios for 16 to 18 year olds for whom school is the major activity $(1968,1978,1988)$ or who are enrolled in school $(1989,1992)$. Source: unpublished Current Population Survey data provided by the U.S. Department of Labor, Bureau of Labor Statistics. 


\begin{tabular}{|c|c|c|}
\hline & $\begin{array}{c}\text { All } \\
\text { Respondents }\end{array}$ & $\begin{array}{l}\text { Respondents } \\
\text { Interviewed } \\
\text { in } 1991\end{array}$ \\
\hline \multicolumn{3}{|l|}{ Demographic Characteristics } \\
\hline Female & $48.8 \%$ & $48.9 \%$ \\
\hline Black & 11.8 & 11.5 \\
\hline Hispanic (Nonblack) & 6.1 & 6.3 \\
\hline Foreign Language Spoken in Home & 10.9 & 11.2 \\
\hline Foreign Born & 2.6 & 2.7 \\
\hline Number of Siblings & 3.0 & 3.0 \\
\hline \multicolumn{3}{|l|}{ Education } \\
\hline Attends Public School & 92.8 & 92.8 \\
\hline Negative Attitude Towards School & 15.5 & 15.3 \\
\hline Highest Grade Expected & $14.3 \mathrm{yrs}$ & $14.3 \mathrm{yrs}$ \\
\hline AFQT Score (1981) & 45.7 & 45.9 \\
\hline \multicolumn{3}{|l|}{ Residence } \\
\hline In Urban Area & $74.1 \%$ & $74.6 \%$ \\
\hline In SMSA & 66.1 & 66.4 \\
\hline \multicolumn{3}{|l|}{ Household Resources at Age 14} \\
\hline Magazines & 73.1 & 73.9 \\
\hline Newspapers & 84.2 & 84.3 \\
\hline Library Card & 74.0 & 74.1 \\
\hline \multicolumn{3}{|l|}{ Drug Use } \\
\hline Used Cigarettes By Sophomore Year & 61.8 & 62.4 \\
\hline Used Marijuana or Hashish By Sophomore Year & 7.8 & 7.9 \\
\hline \multicolumn{3}{|l|}{ Religion: } \\
\hline Baptist & 19.0 & 18.2 \\
\hline Catholic & 33.1 & 33.6 \\
\hline Jewish & 1.1 & 1.0 \\
\hline \multicolumn{3}{|l|}{ Characteristics of Mother } \\
\hline Foreign Born & 5.8 & 6.2 \\
\hline High School Graduate & 69.8 & 69.7 \\
\hline College Graduate & 11.1 & 10.8 \\
\hline \multicolumn{3}{|l|}{ Characteristics of Father } \\
\hline Foreign Born & 5.7 & 5.8 \\
\hline High School Graduate & 67.1 & 67.5 \\
\hline College Graduate & 18.4 & 18.4 \\
\hline $\mathbf{N}$ & 1,149 & 1,067 \\
\hline
\end{tabular}

Note: Unless otherwise specified in the text of the paper, all variables are obtained from 1979 interview and refer to 1979. Respondent is defined to have negative attitudes towards school if they respond that either of the statements "most of my classes are boring" or "I don't feel safe at this school" are "very true" or if they say that they are "very dissatisfied" with their school. 


\begin{tabular}{|c|c|c|c|c|c|c|}
\hline & \multicolumn{2}{|c|}{ Sophomores } & \multicolumn{2}{|c|}{ Juniors } & \multicolumn{2}{|c|}{ Seniors } \\
\hline & (a) & (b) & (a) & (b) & (a) & (b) \\
\hline \multicolumn{7}{|c|}{ Employment Status in Reference Week } \\
\hline Percent Working & $27.9 \%$ & $28.3 \%$ & $42.4 \%$ & $43.3 \%$ & $50.3 \%$ & $50.8 \%$ \\
\hline Ave. Hours Week & $3.3 \mathrm{hr}$ & $3.3 \mathrm{hr}$ & $6.6 \mathrm{hr}$ & $6.7 \mathrm{hr}$ & $9.4 \mathrm{hr}$ & $9.6 \mathrm{hr}$ \\
\hline Ave. Hours Week if Employed & $11.9 \mathrm{hr}$ & $11.8 \mathrm{hr}$ & $15.5 \mathrm{hr}$ & $15.5 \mathrm{hr}$ & $18.7 \mathrm{hr}$ & $18.9 \mathrm{hr}$ \\
\hline \multicolumn{7}{|c|}{ Hours Worked in Week Prior to Survey } \\
\hline 0 & $72.2 \%$ & $71.8 \%$ & $57.6 \%$ & $56.6 \%$ & $49.7 \%$ & $49.2 \%$ \\
\hline $1-10$ & 16.3 & 16.4 & 15.4 & 15.8 & 11.3 & 11.3 \\
\hline $11-20$ & 8.1 & 8.5 & 17.1 & 17.5 & 20.5 & 20.5 \\
\hline $21-30$ & 2.2 & 2.3 & 7.6 & 7.7 & 13.4 & 13.8 \\
\hline $31-40$ & 0.7 & 0.7 & 2.0 & 2.1 & 4.1 & 4.2 \\
\hline$>40$ & 0.5 & 0.4 & 0.4 & 0.4 & 1.0 & 1.0 \\
\hline
\end{tabular}

\section{Academic Year Employment (From Work History File)}

$\begin{array}{lrrrr}\text { Percent Employed } \geq 1 \text { Week } & 63.9 \% & 64.9 \% & 72.6 \% & 73.4 \% \\ \text { Percent of Weeks Employed } & 41.5 \% & 42.6 \% & 51.5 \% & 52.3 \% \\ \text { Ave. Hours } \text { Week } & 7.7 \mathrm{hr} & 8.0 \mathrm{hr} & 12.1 \mathrm{hr} & 12.3 \mathrm{hr} \\ \text { Ave. Hours } \text { Week if Employed } & 18.6 \mathrm{hr} & 18.9 \mathrm{hr} & 23.5 \mathrm{hr} & 23.5 \mathrm{hr}\end{array}$

\section{Summer Employment (From Work History File)}

Percent Employed $\geq 1$ Week

Percent of Weeks Employed

Ave. Hours Week

Ave. Hours/Week if Employed

$\begin{array}{llll}56.2 \% & 57.2 \% & 59.6 \% & 60.8 \% \\ 44.1 \% & 45.0 \% & 48.5 \% & 49.6 \% \\ 10.2 \mathrm{hr} & 10.3 \mathrm{hr} & 13.7 \mathrm{hr} & 14.0 \mathrm{hr} \\ 23.1 \mathrm{hr} & 23.0 \mathrm{hr} & 28.2 \mathrm{hr} & 28.1 \mathrm{hr}\end{array}$

Note: Full sample included in column (a), $n=1149$. Column (b) includes respondents interviewed in 1991, $n=1067$. Academic year employment status calculated for 26 week periods covering the months of October, November, February, March, April, and May of the relevant survey years. Summer employment status refers to 8 week periods beginning with the week which includes July 1 of the summer before the specified high school year. 
Table 5:

Economic Outcomes as a Function of High School Employment Hours

\begin{tabular}{|c|c|c|c|c|c|}
\hline \multirow[b]{2}{*}{$\begin{array}{l}\text { High School } \\
\text { Employment } \\
\text { Hours }\end{array}$} & \multirow[b]{2}{*}{$\mathbf{N}$} & \multicolumn{3}{|c|}{ Outcome Measure (1988-90 Average) } & \multirow[b]{2}{*}{$\begin{array}{c}\text { Employer } \\
\text { Pension } \\
\text { Plan }\end{array}$} \\
\hline & & $\begin{array}{c}\text { Annual } \\
\text { Earnings }\end{array}$ & $\begin{array}{l}\text { Duncan } \\
\text { Occupation } \\
\text { Index }\end{array}$ & $\begin{array}{c}\text { Employer } \\
\text { Health } \\
\text { Insurance }\end{array}$ & \\
\hline All Respondents & 1,067 & $\$ 16,513$ & 42.4 & $75.6 \%$ & $53.6 \%$ \\
\hline \multicolumn{6}{|c|}{ Employment Status in Reference Week } \\
\hline $\begin{array}{c}0 \\
1-20 \\
>20\end{array}$ & $\begin{array}{r}766 \\
266 \\
35\end{array}$ & $\begin{array}{l}\$ 16,012 \\
\$ 17,846 \\
\$ 17,441\end{array}$ & $\begin{array}{l}42.1 \\
44.3 \\
34.0\end{array}$ & $\begin{array}{l}75.2 \% \\
77.5 \% \\
71.1 \%\end{array}$ & $\begin{array}{l}54.1 \% \\
52.3 \% \\
53.9 \%\end{array}$ \\
\hline \multicolumn{6}{|c|}{ Junior Work Hours } \\
\hline $\begin{array}{c}0 \\
1-20 \\
>20\end{array}$ & $\begin{array}{l}604 \\
355 \\
108\end{array}$ & $\begin{array}{l}\$ 15,086 \\
\$ 17,969 \\
\$ 19,739\end{array}$ & $\begin{array}{l}41.5 \\
44.1 \\
41.3\end{array}$ & $\begin{array}{l}74.0 \% \\
77.2 \% \\
79.9 \%\end{array}$ & $\begin{array}{l}52.9 \% \\
54.5 \% \\
55.0 \%\end{array}$ \\
\hline \multicolumn{6}{|c|}{ Senior Work Hours } \\
\hline $\begin{array}{c}0 \\
1-20 \\
>20\end{array}$ & $\begin{array}{l}525 \\
339 \\
203\end{array}$ & $\begin{array}{l}\$ 14,422 \\
\$ 17,949 \\
\$ 19,510\end{array}$ & $\begin{array}{l}39.6 \\
45.8 \\
43.6\end{array}$ & $\begin{array}{l}70.7 \% \\
80.8 \% \\
79.7 \%\end{array}$ & $\begin{array}{l}49.6 \% \\
58.3 \% \\
56.1 \%\end{array}$ \\
\hline \multicolumn{6}{|c|}{ Academic Year Work Hours (From Work History File) } \\
\hline $\begin{array}{c}0 \\
1-20 \\
>20\end{array}$ & $\begin{array}{l}370 \\
553 \\
139\end{array}$ & $\begin{array}{l}\$ 13,856 \\
\$ 17,592 \\
\$ 19,241\end{array}$ & $\begin{array}{l}40.4 \\
44.1 \\
40.7\end{array}$ & $\begin{array}{l}72.3 \% \\
77.1 \% \\
77.9 \%\end{array}$ & $\begin{array}{l}53.7 \% \\
52.2 \% \\
58.9 \%\end{array}$ \\
\hline \multicolumn{6}{|c|}{ Senior Work Hours } \\
\hline $\begin{array}{c}0 \\
1-20 \\
>20\end{array}$ & $\begin{array}{l}282 \\
494 \\
289\end{array}$ & $\begin{array}{l}\$ 12,765 \\
\$ 16,703 \\
\$ 19,789\end{array}$ & $\begin{array}{l}37.7 \\
43.4 \\
44.9\end{array}$ & $\begin{array}{l}69.9 \% \\
75.0 \% \\
81.9 \%\end{array}$ & $\begin{array}{l}51.7 \% \\
51.7 \% \\
58.3 \%\end{array}$ \\
\hline
\end{tabular}

Note: Sample includes respondents interviewed in 1991. Table shows average values of outcome variables for 1988-90 time period. If data is missing for one interview, the average is calculated for the remaining two years. 
Table 6:

Regression Estimates of Log Earnings on High School Employment Hours

\begin{tabular}{|c|c|c|c|c|c|}
\hline \multirow{2}{*}{$\begin{array}{l}\text { Type } \\
\text { of } \\
\text { Employment }\end{array}$} & \multicolumn{5}{|c|}{ Regression Specification } \\
\hline & (a) & (b) & (c) & (d) & (e) \\
\hline \multicolumn{6}{|c|}{ Employment Hours in Reference Week } \\
\hline $\begin{array}{l}\text { Sophomore Hours } \\
\text { Hours Squared } \\
\text { P-Value }\end{array}$ & $\begin{array}{r}.0171 \\
-4.4 \mathrm{E}-4 \\
{[.193]}\end{array}$ & $\begin{array}{r}.0055 \\
-2.4 E-4 \\
{[.683]}\end{array}$ & $\begin{array}{r}.0013 \\
-1.5 \mathrm{E}-4 \\
{[.642]}\end{array}$ & $\begin{array}{r}.0016 \\
-6.8 \mathrm{E}-5 \\
{[.966]}\end{array}$ & $\begin{array}{r}4.8 \mathrm{E}-4 \\
-3.7 \mathrm{E}-5 \\
{[.980]}\end{array}$ \\
\hline $\begin{array}{l}\text { Junior Hours } \\
\text { Hours Squared } \\
\text { P-Value }\end{array}$ & $\begin{array}{r}.0202 \\
-3.8 E-4 \\
{[.005]}\end{array}$ & $\begin{array}{r}.0100 \\
-1.1 \mathrm{E}-4 \\
{[.173]}\end{array}$ & $\begin{array}{r}.0050 \\
-8.5 E-5 \\
{[.701]}\end{array}$ & $\begin{array}{r}.0013 \\
-1.7 E-5 \\
{[.878]}\end{array}$ & $\begin{array}{r}.0013 \\
1.6 \mathrm{E}-5 \\
{[.877]}\end{array}$ \\
\hline $\begin{array}{l}\text { Senior Hours } \\
\text { Hours Squared } \\
\text { P-Value }\end{array}$ & $\begin{array}{r}.0238 \\
-4.6 \mathrm{E}-4 \\
{[.000]}\end{array}$ & $\begin{array}{r}.0210 \\
-4.5 \mathrm{E}-4 \\
{[.008]}\end{array}$ & $\begin{array}{r}.0185 \\
-3.7 \mathrm{E}-4 \\
{[.007]}\end{array}$ & $\begin{array}{r}.0178 \\
-3.7 \mathrm{E}-4 \\
{[.014]}\end{array}$ & $\begin{array}{r}.0168 \\
-3.4 E-4 \\
{[.019]}\end{array}$ \\
\hline
\end{tabular}

Academic Year Employment Hours (From Work History File)

$\begin{array}{lrrrrr}\text { Junior Hours } & .0286 & .0155 & .0068 & .0041 & .0056 \\ \quad \text { Hours Squared } & -8.0 \mathrm{E}-4 & -6.1 \mathrm{E}-4 & -3.8 \mathrm{E}-4 & -2.6 \mathrm{E}-4 & -2.8 \mathrm{E}-4 \\ \text { P-Value } & {[.004]} & {[.243]} & {[.371]} & {[.601]} & {[.610]} \\ & & & & & \\ \text { Senior Hours } & .0234 & .0176 & .0151 & .0138 & .0120 \\ \quad \text { Hours Squared } & -3.7 \mathrm{E}-4 & -2.0 \mathrm{E}-4 & -1.9 \mathrm{E}-4 & -2.0 \mathrm{E}-4 & -1.5 \mathrm{E}-4 \\ \quad \text { P-Value } & {[.000]} & {[.002]} & {[.008]} & {[.036]} & {[.062]}\end{array}$

Notes:

1. Sample includes respondents interviewed in 1991. Outcome measures are three-year averages for the 1988-90 period. Table displays regression coefficients on work hours and work hours squared $(n=990)$. P-Value of the hypothesis that the coefficients on hours worked and hours worked squared are jointly equal to zero (obtained from $\mathrm{F}$ tests) is displayed in brackets.

2. Model (a) shows results from regressions which control for work hours in a single high school class. In model (b), hours in all high school grades are controlled for (sophomore, junior, and senior hours in the top panel; junior and senior hours in the bottom panel). Model (c) adds regressors for the high school grade in 1979, ethnic status (black, Hispanic, white), sex, marital status, geographic region (4 categories), residence in an SMSA and urban area, and the local unemployment rate (5 categories). Model (d) includes the covariates in (c) plus: whether the respondent and his/her parents are foreign bom, if a foreign language was spoken in the home when the respondent was a child, mother and father's educational attainment (4 categories each), whether magazines, newspapers, or library card were in the home when the respondent was 14, number of siblings, religion (4 categories), educational attitudes (if the respondent considered his school boring, unsafe, or was very dissatisfied with the school), educational expectations, type of school at 1979 survey date (public vs. private), whether the respondent had smoked cigarettes or used marijuana or hashish by the sophomore year of high school, the log of average family incomes during the respondent's sophomore through senior years, and (in the lower panel) work hours and hours squared in the sophomore reference week. Model (e) includes these variables, plus the (1981) AFQT score. 
Table 7:

Additional Regression Estimates of Log Earnings on High School Employment

\begin{tabular}{llllll}
\hline $\begin{array}{c}\text { Type } \\
\text { of } \\
\text { Employment }\end{array}$ & \multicolumn{3}{c}{ Full Sample Estimates } & Males & Females \\
\cline { 2 - 6 } & (a) & (b) & (c) & (d) & (e) \\
\hline
\end{tabular}

\section{Employment Hours in Reference Week}

$\begin{array}{lrrr}\text { Sophomore Hours } & 4.8 \mathrm{E}-4 & .0134 & -.0199 \\ \text { Hours Squared } & -3.7 \mathrm{E}-5 & -4.5 \mathrm{E}-4 & 9.7 \mathrm{E}-4 \\ \text { P-Value } & {[.980]} & {[.167]} & {[.551]} \\ & & & \\ \text { Junior Hours } & .0013 & 7.8 \mathrm{E}-4 & .0064 \\ \quad \text { Hours Squared } & 1.6 \mathrm{E}-5 & 4.1 \mathrm{E}-5 & -2.1 \mathrm{E}-4 \\ \quad \text { P-Value } & {[.877]} & {[.821]} & {[.936]} \\ & & & \\ \text { Senior Hours } & .0168 & .0146 & .0290 \\ \quad \text { Hours Squared } & -3.4 \mathrm{E}-4 & -2.5 \mathrm{E}-4 & -8.1 \mathrm{E}-4 \\ \text { P-Value } & {[.019]} & {[.038]} & {[.110]}\end{array}$

Academic Year Employment Hours or Weeks (From Work History File)

Junior Hours/Weeks Hrs $M k s$ Squared P-Value

Senior Hours Weeks Hrs Nks Squared P-Value

Summer Hours Hours Squared P-Value

$$
.0056
$$

[.610]

.0120

$-1.5 \mathrm{E}-4$

[.062]

$$
\begin{array}{r}
.0065 \\
-3.0 \mathrm{E}-4 \\
{[.646]} \\
\\
.0092 \\
-9.1 \mathrm{E}-5 \\
{[.131]} \\
\\
.0049 \\
-1.3 \mathrm{E}-4 \\
{[.350]}
\end{array}
$$$$
.0010
$$$$
-5.3 E-4
$$$$
\text { [.386] }
$$$$
.0076
$$$$
3.5 \mathrm{E}-6
$$$$
\text { [.059] }
$$$$
\begin{array}{r}
.0031 \\
-4.7 E-5 \\
{[.886]} \\
\\
.0076 \\
-4.7 E-5 \\
{[.143]}
\end{array}
$$

4.1E-4

$-4.6 \mathrm{E}-4$

Note: See notes on table 6. Table presents coefficients on linear and quadratic terms for hours (or weeks) worked. P-Values (obtained from F or likelihood ratio tests) are shown in brackets. Additional covariates are the same as in specification (e) of table 6 and employment coefficients from that specification are displayed in column (a). Column (b) includes controls for average hours worked during an eight week period beginning with the week which includes July 1 of the summer before the senior year of high school. In column (c), the number of weeks, rather than hours/week, of academic year employment, are controlled for. Columns (d) and (e) present estimates for the same specification as column (a), for subsamples of males $(n=512)$ and females $(n=471)$. 
Table 8:

Regression Estimates for Log Earnings By Educational Status

\begin{tabular}{lccc}
\hline $\begin{array}{c}\text { Type of } \\
\text { Employment }\end{array}$ & $\begin{array}{c}\text { Full } \\
\text { Sample }\end{array}$ & $\begin{array}{c}\text { No } \\
\text { College }\end{array}$ & $\begin{array}{c}\text { Some } \\
\text { College }\end{array}$ \\
& (a) & (b) & (c)
\end{tabular}

Employment Hours in Reference Week

$\begin{array}{lrrr}\text { Sophomore Hours } & 4.8 \mathrm{E}-4 & -.0104 & .0166 \\ \quad \text { Hours Squared } & -3.7 \mathrm{E}-5 & 2.3 \mathrm{E}-4 & -6.7 \mathrm{E}-4 \\ \text { P-Value } & {[.980]} & {[.755]} & {[.352]} \\ & & & \\ \text { Junior Hours } & .0013 & .0046 & -.0017 \\ \quad \text { Hours Squared } & 1.6 \mathrm{E}-5 & 1.4 \mathrm{E}-4 & 3.0 \mathrm{E}-4 \\ \quad \text { P-Value } & {[.877]} & {[.952]} & {[.280]} \\ & & & .0117 \\ \text { Senior Hours } & .0168 & .0232 & -3.1 \mathrm{E}-4 \\ \quad \text { Hours Squared } & -3.4 \mathrm{E}-4 & -4.0 \mathrm{E}-4 & {[.378]} \\ \text { P-Value } & {[.019]} & {[.033]} & \end{array}$

Academic Year Employment Hours (From Work History File)

$\begin{array}{lrrr}\text { Junior Hours Weeks } & .0056 & .0170 & -.0080 \\ \text { Hrs } M k s \text { Squared } & -2.8 \mathrm{E}-4 & -9.4 \mathrm{E}-4 & 5.4 \mathrm{E}-4 \\ \text { P-Value } & {[.610]} & {[.089]} & {[.230]} \\ & & & \\ \text { Senior Hours } \text { Weeks } & .0120 & .0088 & .0135 \\ \text { Hrs } M k s \text { Squared } & -1.5 \mathrm{E}-4 & 8.7 \mathrm{E}-5 & -2.7 \mathrm{E}-4 \\ \text { P-Value } & {[.062]} & {[.039]} & {[.299]}\end{array}$

Note: See notes on table 6 and 7. Column (a) is the same as model (e) of table 6. Columns (b) and (c) present estimates for the same specification but for subsamples of persons never attending college $(n=463)$ and for those with completing at least one year of university $(n=515)$. 
Table 9:

Two-Stage and Restricted Sample Estimates of the Effects of Senior Year Employment

\begin{tabular}{|c|c|c|c|c|c|}
\hline \multirow{2}{*}{$\begin{array}{l}\text { Reference } \\
\text { Week } \\
\text { Employment } \\
\text { Hours }\end{array}$} & \multicolumn{3}{|c|}{ No Work Restriction } & \multirow{2}{*}{$\begin{array}{c}\text { Works } \\
\geq 1000 \\
\text { Hours } \\
\text { (d) }\end{array}$} & \multirow{2}{*}{$\begin{array}{c}\text { Works } \\
\geq 26 \\
\text { Weeks } \\
\text { (e) }\end{array}$} \\
\hline & $\begin{array}{l}\text { OLS } \\
\text { (a) }\end{array}$ & $\begin{array}{c}\text { Treatment-Effects } \\
\text { (b) }\end{array}$ & $\begin{array}{l}\text { IV } \\
\text { (c) }\end{array}$ & & \\
\hline \multicolumn{6}{|c|}{ Full Sample } \\
\hline Senior Hours & $\begin{array}{l}.0168 \\
(.0066)\end{array}$ & $\begin{array}{c}.0199 \\
(.0120)\end{array}$ & $\begin{array}{c}.1093 \\
(.2625)\end{array}$ & $\begin{array}{c}.0119 \\
(.0041)\end{array}$ & $\begin{array}{l}.0106 \\
(.0045)\end{array}$ \\
\hline Hours Squared & $\begin{array}{l}-3.4 E-4 \\
(1.9 E-4)\end{array}$ & $\begin{array}{l}-4.0 E-4 \\
(2.6 E-4)\end{array}$ & $\begin{array}{l}-.0048 \\
(.0064)\end{array}$ & $\begin{array}{l}-1.8 E-4 \\
(1.2 E-4)\end{array}$ & $\begin{array}{l}-2.2 E-4 \\
(1.3 E-4)\end{array}$ \\
\hline P-Value & {$[.019]$} & {$[.249]$} & {$[.519]$} & {$[.001]$} & {$[.040]$} \\
\hline Inverse Mills Ratio & & $\begin{array}{l}-.0252 \\
(.0812)\end{array}$ & & & \\
\hline \multicolumn{6}{|c|}{ Respondents Never Attending College } \\
\hline $\begin{array}{l}\text { Senior Hours } \\
\text { Hours Squared } \\
\text { P-Value }\end{array}$ & $\begin{array}{r}.0232 \\
-4.0 E-4 \\
{[.033]}\end{array}$ & $\begin{array}{r}.0349 \\
-6.0 E-4 \\
{[.131]}\end{array}$ & $\begin{array}{r}.1483 \\
-.0047 \\
{[.813]}\end{array}$ & $\begin{array}{r}.0142 \\
-2.0 E-4 \\
{[.007]}\end{array}$ & $\begin{array}{r}.0121 \\
-2.0 \mathrm{E}-4 \\
{[.111]}\end{array}$ \\
\hline Inverse Mills Ratio & & $\begin{array}{l}-.1017 \\
(.1298)\end{array}$ & & & \\
\hline \multicolumn{6}{|c|}{ College Educated Respondents } \\
\hline $\begin{array}{l}\text { Senior Hours } \\
\text { Hours Squared } \\
\text { P-Value }\end{array}$ & $\begin{array}{r}.0117 \\
-3.1 \mathrm{E}-4 \\
{[.378]}\end{array}$ & $\begin{array}{r}.0139 \\
-3.6 E-4 \\
{[.588]}\end{array}$ & $\begin{array}{l}-.3305 \\
-.0076 \\
{[.880]}\end{array}$ & $\begin{array}{r}.0103 \\
-2.0 E-4 \\
{[.108]}\end{array}$ & $\begin{array}{r}.0096 \\
-2.7 E-4 \\
{[.286]}\end{array}$ \\
\hline Inverse Mills Ratio & & $\begin{array}{l}-.0154 \\
(.0951)\end{array}$ & & & \\
\hline
\end{tabular}

Note: See notes on tables 6,7 and 8. Standard errors are shown in parentheses. Work hours refer to the interview week of the senior year in high school. Column (b) shows results of an equation which corrects for selection bias by including the inverse Mills ratio from probit estimates of the probability of working positive hours in the senior grade. Column (c) displays instrumental variable estimates. Columns (d) and (e) indicate OLS estimates for samples restricted to persons averaging at least 1000 hours and 26 weeks of work per year, respectively, between 1988 and 1990 ( $n=866$ and 883 in the top panel). 
Table 10:

OLS and Tobit Estimates of Wages and Employment Levels on Reference Week Employment in the Senior Year of High School and Other Covariates

\begin{tabular}{|c|c|c|c|c|}
\hline $\begin{array}{c}\text { Reference } \\
\text { Week } \\
\text { Employment } \\
\text { Hours }\end{array}$ & $\begin{array}{c}\text { Weekly } \\
\text { Wages } \\
\text { (a) }\end{array}$ & $\begin{array}{c}\text { Hourly } \\
\text { Wages } \\
\text { (b) }\end{array}$ & $\begin{array}{c}\text { Annual } \\
\text { Weeks } \\
\text { Worked } \\
\text { (c) }\end{array}$ & $\begin{array}{l}\text { Annual } \\
\text { Hours } \\
\text { Worked } \\
\text { (d) }\end{array}$ \\
\hline \multicolumn{5}{|c|}{ Full Sample } \\
\hline $\begin{array}{l}\text { Senior Hours } \\
\text { Hours Squared } \\
\text { P-Value }\end{array}$ & $\begin{array}{r}.0096 \\
-2.0 E-4 \\
{[.088]}\end{array}$ & $\begin{array}{r}.0095 \\
-2.2 E-4 \\
{[.067]}\end{array}$ & $\begin{array}{r}.4551 \\
-.0061 \\
{[.000]}\end{array}$ & $\begin{array}{r}10.006 \\
-.369 \\
{[.000]}\end{array}$ \\
\hline$\Phi(\bullet)$ & & & .547 & .979 \\
\hline \multicolumn{5}{|c|}{ Respondents Never Attending College } \\
\hline $\begin{array}{l}\text { Senior Hours } \\
\text { Hours Squared } \\
\text { P-Value }\end{array}$ & $\begin{array}{r}.0142 \\
-2.5 E-4 \\
{[.074]}\end{array}$ & $\begin{array}{r}.0126 \\
-2.2 E-4 \\
{[.077]}\end{array}$ & $\begin{array}{r}.5076 \\
-.0059 \\
{[.001]}\end{array}$ & $\begin{array}{r}11.089 \\
-.0575 \\
{[.001]}\end{array}$ \\
\hline$\Phi(\bullet)$ & & & .551 & .963 \\
\hline \multicolumn{5}{|c|}{ College Educated Respondents } \\
\hline $\begin{array}{l}\text { Senior Hours } \\
\text { Hours Squared } \\
\text { P-Value }\end{array}$ & $\begin{array}{r}.0045 \\
-1.3 E-4 \\
{[.772]}\end{array}$ & $\begin{array}{r}.0065 \\
-2.4 E-4 \\
{[.342]}\end{array}$ & $\begin{array}{r}.4412 \\
-.0080 \\
{[.021]}\end{array}$ & $\begin{array}{r}10.183 \\
-.1211 \\
{[.005]}\end{array}$ \\
\hline$\Phi(\bullet)$ & & & .537 & .989 \\
\hline
\end{tabular}

Note: See notes on tables 6, 7, and 8 . Estimation is by OLS in columns (a) and (b) and as Tobit models in (c) and (d). Sample sizes (in the top panel) are $979,980,1048$, and 1050 in columns (a) through (d) respectively, with 44 observations are left-censored at zero hours or weeks and 394 are right-censored at 52 weeks. $\Phi(\bullet)$ is the predicted percentage of noncensored observations (estimated as the average value of $\Phi(X \beta / \sigma)$ in the single limit Tobit case). 
Table 11:

Regression and Ordered Probit Estimates of Duncan Scores, Fringe

Benefits and Educational Attainment on Reference Week Employment in

Senior Year of High School and Other Covariates

\begin{tabular}{|c|c|c|c|c|}
\hline $\begin{array}{l}\text { Reference } \\
\text { Week } \\
\text { Employment } \\
\text { Hours }\end{array}$ & $\begin{array}{l}\text { Duncan } \\
\text { Occupation } \\
\text { Index } \\
\text { (a) }\end{array}$ & $\begin{array}{c}\text { Employer } \\
\text { Health } \\
\text { Insurance } \\
\text { (b) }\end{array}$ & $\begin{array}{l}\text { Employer } \\
\text { Pension } \\
\text { Plan } \\
\text { (c) }\end{array}$ & $\begin{array}{c}\text { Highest } \\
\text { Grade } \\
\text { Completed } \\
\text { (d) }\end{array}$ \\
\hline \multicolumn{5}{|c|}{ Full Sample } \\
\hline $\begin{array}{l}\text { Senior Hours } \\
\text { Hours Squared } \\
\text { P-Value }\end{array}$ & $\begin{array}{r}.3532 \\
-.0075 \\
{[.012]}\end{array}$ & $\begin{array}{r}.0242 \\
-4.4 E-4 \\
{[.009]}\end{array}$ & $\begin{array}{r}.0311 \\
-8.0 E-4 \\
{[.002]}\end{array}$ & $\begin{array}{c}-.0041 \\
-3.2 E-4 \\
{[.006]}\end{array}$ \\
\hline \multicolumn{5}{|c|}{ Respondents Never Attending College } \\
\hline $\begin{array}{l}\text { Senior Hours } \\
\text { Hours Squared } \\
\text { P-Value }\end{array}$ & $\begin{array}{r}.4407 \\
-.0064 \\
{[.001]}\end{array}$ & $\begin{array}{r}.0076 \\
-7.3 E-6 \\
{[.443]}\end{array}$ & $\begin{array}{r}.0197 \\
-4.7 E-4 \\
{[.271]}\end{array}$ & \\
\hline \multicolumn{5}{|c|}{ College Educated Respondents } \\
\hline $\begin{array}{l}\text { Senior Hours } \\
\text { Hours Squared } \\
\text { P-Value }\end{array}$ & $\begin{array}{r}.2714 \\
-.0078 \\
{[.390]}\end{array}$ & $\begin{array}{r}.0426 \\
-8.7 E-4 \\
{[.003]}\end{array}$ & $\begin{array}{r}.0452 \\
-.0012 \\
{[.003]}\end{array}$ & \\
\hline
\end{tabular}

Note: See notes on tables 6, 7, and 8. The Duncan score and grade completion equations are estimated using OLS. Ordered probit models are used for employer health insurance and pension coverage. The dependent variable in these equations is equal to 0,1 , and 2 if the fringe benefit is provided at none, some, or all or the three interview dates, respectively. P-Values for these cases are obtained from likelihood ratio tests. Missing values on the dependent variables reduce the sample sizes, in the top panel, to $1000,961,961,1045$, respectively, for the Duncan index, health insurance, pension coverage, and grade completion. 
Table 12:

Change in Economic Attainment Associated With Employment In the Reference Week of the Senior Year in High School

\begin{tabular}{|c|c|c|c|c|c|}
\hline $\begin{array}{l}\text { Reference } \\
\text { Week } \\
\text { Employment } \\
\text { Hours }\end{array}$ & $\begin{array}{c}\text { Annual } \\
\text { Earnings } \\
\text { (a) }\end{array}$ & $\begin{array}{c}\text { Hourly } \\
\text { Wages } \\
\text { (b) }\end{array}$ & $\begin{array}{l}\text { Duncan } \\
\text { Occupation } \\
\text { Index } \\
\text { (c) }\end{array}$ & $\begin{array}{c}\text { Employer } \\
\text { Health } \\
\text { Insurance } \\
\text { (d) }\end{array}$ & $\begin{array}{c}\text { Employer } \\
\text { Pension } \\
\text { Plan } \\
\text { (e) }\end{array}$ \\
\hline \multicolumn{6}{|c|}{ Differentials for Full Sample } \\
\hline 10 Hours & $14.3 \%$ & $7.7 \%$ & $2.8 \mathrm{pts}$. & .075 & .087 \\
\hline 20 Hours & 22.1 & 11.0 & 4.1 & .114 & .115 \\
\hline 40 Hours & 13.4 & 3.8 & 2.1 & .097 & -.015 \\
\hline Max. Difference & $24.6 \mathrm{hr}$ & $22.2 \mathrm{hr}$ & $23.5 \mathrm{hr}$ & $27.3 \mathrm{hr}$ & $19.4 \mathrm{hr}$ \\
\hline
\end{tabular}

Differentials for Respondents Without College Educations

\begin{tabular}{lccccc}
10 Hours & $21.1 \%$ & $11.0 \%$ & $3.8 \mathrm{pts}$. & .029 & .054 \\
20 Hours & 35.4 & 18.0 & 6.3 & .057 & .075 \\
40 Hours & 32.9 & 16.8 & 7.4 & .110 & .011 \\
Max. Difference & $28.9 \mathrm{hr}$ & $57.8 \mathrm{hr}$ & $34.4 \mathrm{hr}$ & $>100 \mathrm{hr}$ & $20.8 \mathrm{hr}$ \\
\hline & Differentials for College Educated Respondents & \\
10 Hours & $9.0 \%$ & $4.1 \%$ & $1.9 \mathrm{pts}$. & .126 & .129 \\
20 Hours & 11.5 & 3.3 & 2.3 & .180 & .166 \\
40 Hours & -3.1 & -12.0 & -1.7 & .118 & -.039 \\
Max. Difference & $18.7 \mathrm{hr}$ & $13.4 \mathrm{hr}$ & $17.3 \mathrm{hr}$ & $24.6 \mathrm{hr}$ & $18.9 \mathrm{hr}$ \\
\hline
\end{tabular}

Note: See notes on tables $6,8,10$, and 11. Table shows difference in predicted outcomes compared to persons not working in the reference week of the senior year. Columns (d) and (e) indicate the probability that the respondent receives employer health insurance or pension coverage at the time of the 1988, 1989 , and 1990 surveys. Sample averages for the Duncan Index and probabilities of receiving health insurance and pension coverage from the employer are 42.4 points, .623 , and .375 respectively. 
Table A.1:

Coefficients from Regression of Log Earnings on High

School Employment Hours and Covariates

Regression

Coefficlent
Absolute Value of

T-Statistic
Sophomore in 1979

Ethnic Status: Black

Hispanic

Female

Married

Resides in: Northeast

Northcentral

South

SMSA

Urban Area

Local Unemployment Rate: $<3 \%$

$$
\begin{aligned}
& 3-6 \% \\
& 6-9 \% \\
& 9-12 \% \\
& >12 \%
\end{aligned}
$$

Respondent is Foreign Born

Mother is Foreign Born

Father is Foreign Born

Foreign Language Spoken in the Home

Mother's Education: High School Dropout

High School Graduate

College Graduate

Father's Education: High School Dropout High School Graduate College Graduate

Magazines in Home (at 14)

Newspaper in Home (at 14)

Library Card in Home (at 14)

Number of Siblings

Attends Public School (1979)

Educational Expectations

Negative Attitude Concerning School

Religion: Baptist Catholic Jewish

Has Smoked Cigarette (by Sophomore Year) Marijuana/Hashish Use (by Sophomore Year) Natural Log of Ave. Family Income AFQT Score (1981)
.0478

$-.2756$

$-.1396$

$-.5398$

$-.0236$

.1857

.0502

.1981

$-.0916$

.1423

2.0889

1.7228

1.4293

1.3110

1.0680

$-.1240$

.1902

.1119

.0305

$-.1800$

$-.0978$

$-.1585$

.2249

.1964

.1823

$-.0057$

.0278

$-.0664$

.0178

$-.1571$

.0348

$-.1440$

$-.0168$

$-.0154$

.0217

$-.0482$

$-.0717$

.1520

.0049
(0.81)

Note: See note on table 6. The dependent variable is the natural log of average annual earnings in 1988 through 1990. Work hours and hours squared in the sophomore, junior, and senior year (of high school) interview weeks is also controlled for. These coefficients are shown in specification (e) of the top panel of table 6. 